\title{
Geology of the Souter Head subvolcanic complex, Aberdeenshire, Scotland: an Ordovician granite-related $\mathrm{Mo}-(\mathrm{Bi}-\mathrm{As}-\mathrm{Au})$ system
}

\author{
Clive M. RICE ${ }^{1 *}$ and Darren F. MARK ${ }^{2}$
}

\author{
${ }^{1}$ Department of Geology and Petroleum Geology, University of Aberdeen, Aberdeen, Scotland AB24 3UE, UK. \\ Email: c.rice@abdn.ac.uk \\ ${ }^{2}$ Isotope Geoscience Unit, Scottish Universities Environmental Research Centre, Rankine Avenue, \\ East Kilbride, Scotland G75 0QF, UK. \\ * Corresponding author
}

\begin{abstract}
An Ordovician subvolcanic intrusive complex hosted by Neoproterozoic metasediments crops out at Souter Head about $6 \mathrm{~km} \mathrm{~S}$ of Aberdeen, Scotland. The complex is composed mainly of two-mica red granite and breccia with minor dykes of pegmatite, quartz porphyry, felsite and dolerite, and widespread quartz veining, hydrothermal alteration and minor molybdenite mineralisation. Anomalous levels of bismuth (Bi), arsenic (As) and gold (Au) occur in quartz-pyrite veins. The complex has been mapped and the major- and minor-element geochemistry, including rare-earth elements of intrusives and mineralisation, has been determined. These data reveal a complex tectonic, intrusive and hydrothermal history. The intrusives are peraluminous and magnetite-, muscovite- and garnet-bearing. The youngest member, a quartz porphyry, is highly fractionated. There are two stages of hydrothermal activity: the first is linked to the explosive release of volatiles from a granite cupola and breccia formation; and the second, widespread quartz veining. Mo is associated with both stages, and $\mathrm{Bi}-\mathrm{As}-\mathrm{Au}$ anomalies are found in late quartz-pyrite veins. The mineralisation is classified as a granite-related vein-type Mo system. The unique preservation, in the Grampian terrane, of an Ordovician subvolcanic complex may be attributed to pre-Devonian movements on the nearby Dee fault and possibly also the collapse of the magma chamber following the explosive release of volatiles. The combination of large size, poor exposure and abundant multi-stage hydrothermal activity suggests that there is potential for further Mo and possibly Au mineralisation in this complex. Further mineralisation of this style may be present in the NE Grampian terrane.
\end{abstract}

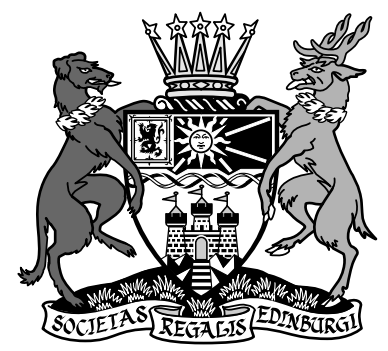

KEY WORDS: mineralisation, molybdenite.

The complex, herein named the Souter Head subvolcanic complex (SHSC), is hosted by Dalradian semi-pelites of the Southern Highland Group and intrudes the sillimanite core of Barrovian metamorphism in NE Scotland (Kneller \& Gillen 1987; Stephenson \& Gould 1995). It is exposed on sea cliffs about $6 \mathrm{~km} \mathrm{~S}$ of Aberdeen (Figs 1, 2a, b). While exposure inland is virtually non-existent, the coastal strip presents a near perfectly exposed transect about 0.1 by $1 \mathrm{~km}$. It reveals a multistage history of repeated intrusion, breccia formation, hydrothermal activity, mineralisation and faulting.

Previous work has described aspects of the geology, intrusive history, geochemistry, hydrothermal fluids, alteration and mineralisation (Porteous 1973; Kneller \& Gillen 1987; Lowry 1991). In 2013, the mineralisation and hydrothermal alteration throughout the complex were examined as part of a regional study of gold $\mathrm{(Au}$ ) mineralisation in the Caledonides of northern Britain (Mark et al. 2011; Rice et al. 2012, 2016) and some minor $\mathrm{Au}$ anomalies were discovered.

This led to a detailed study of the SHSC, which has shown it to be Ordovician rather than Late Caledonian in age, and the only subvolcanic complex of this age known in the Grampian terrane (Mark et al. 2019). This paper provides the first comprehensive description of the geology, quartz veining, hydrothermal alteration, geochemistry of the intrusives and mineralisation, and presents a model for the evolution of the complex.

\section{Regional (NE Scotland) geological setting}

The dominant rock types in NE Scotland are Neoproterozoic metasediments of the Dalradian Supergroup (Strachan et al. 2002). The sediments were deposited on the passive margin of the Laurentian continent and deformed and metamorphosed in the Ordovician following collision with an island arc and crustal fragments (the Grampian event of the Caledonian Orogeny; Strachan et al. 2002). During this event the metasediments were intruded by syn- and late-orogenic (mainly) S-type granitic and basic magmas (Oliver 2001; Strachan et al. 2002; Oliver et al. 2008). Four phases of deformation are commonly recognised in NE Scotland, of which the first three include the main compressional and nappe-building phases. It is the classic area for Barrovian- and Buchan-style metamorphism (Strachan et al. 2002).

The final closure of the Iapetus Ocean in the Silurian introduced a period of continental sedimentation and extensive, mainly granitic, igneous activity (the Newer Granites) extending into the late Devonian. NE Scotland has been largely 


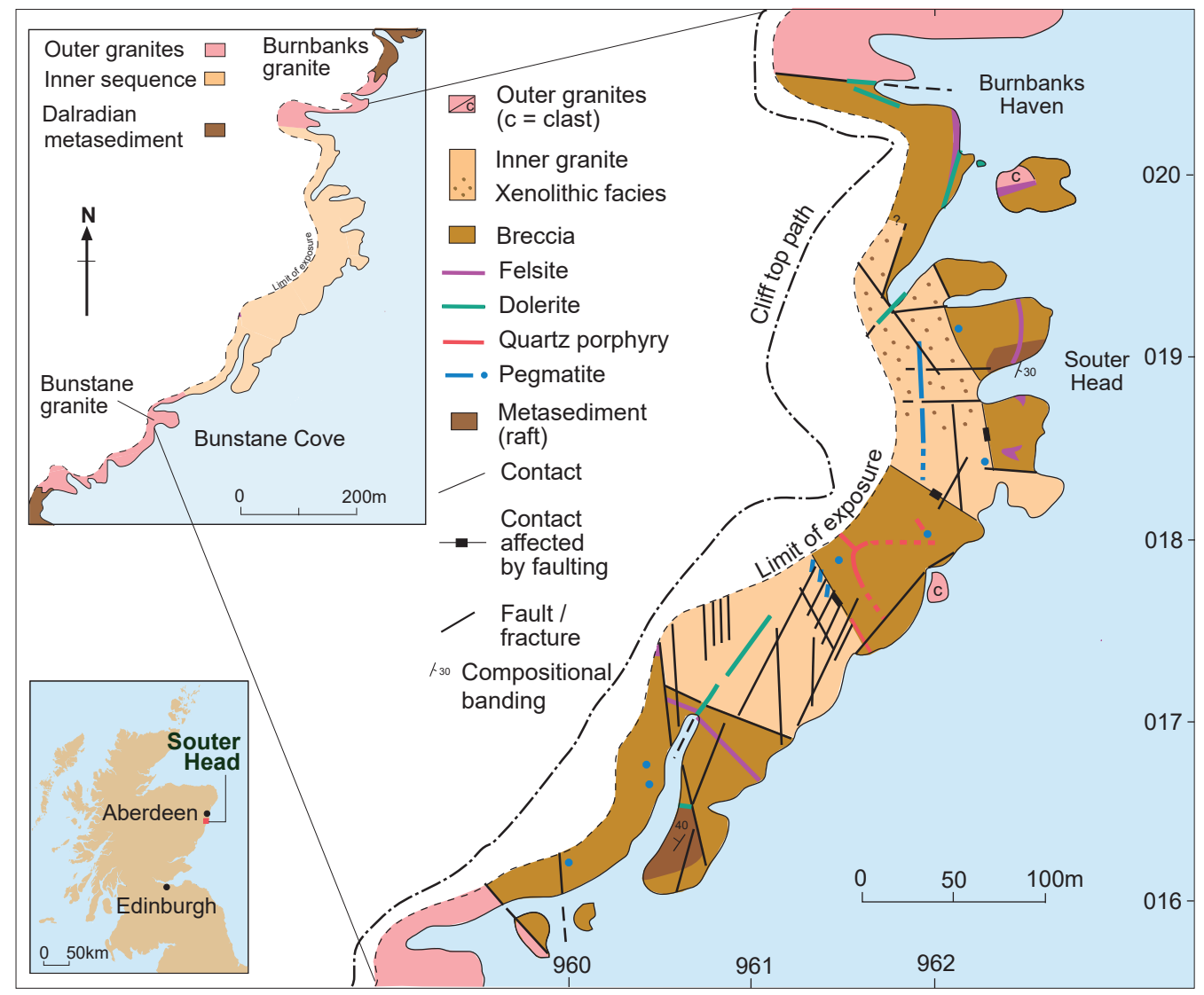

Figure 1 Geological map of the Souter Head subvolcanic complex. Inset: regional location of Souter Head.

emergent from the Devonian to the present day, although there may have been a late Cretaceous marine transgression (Harker 2002). Dolerite dykes of late Carboniferous age are widely distributed and cut the SHSC (Read et al. 2002).

\section{Geology of the SHSC}

\subsection{Igneous lithologies and field relationships}

The dominant rock types are breccia and red two-mica granites. Minor intrusive phases comprise quartz porphyry, pegmatite, felsite and dolerite, which are present as dykes, sills and pipe-like bodies. The contacts between the dominant rock types are mainly faulted, but in a few places original contacts are preserved. The intrusive complex is composed of outer two-mica granites separated by faults from an inner sequence. The former show intrusive relationships with Dalradian country rocks of the Aberdeen Formation (Munro 1986), but the contact between the latter and the Dalradian rocks is not exposed. The relative timing of crystallisation for the inner sequence can be established from field relationships to be, from oldest to youngest: breccia, two-mica granite, pegmatite, quartz porphyry and felsite and, finally, dolerite. Apart from dolerite, all intrusives are cut by quartz veins. These relationships are illustrated and described in the following sections. The SHSC lacks a tectonic foliation and, therefore, emplacement postdates the main episodes of deformation (D1-3) in NE Scotland.

\subsection{The outer granites}

These previously unrecognised granites, referred to as the Burnbanks (northern contact) and Bunstane (southern contact) granites, are in faulted contact with breccia at the margins of the inner sequence and extend for a few $100 \mathrm{~m}$ to an intrusive contact with the metasediments (Fig. 1). The intrusive contacts are not readily accessible, but can be viewed from a distance in the cliffs. They are sharp and consist of sheets of granite generally concordant with the dominant (composite) fabric in the metasediments (Fig. 2b). The Burnbanks granite can be examined by an old landing stage accessed with care by a steep path down the cliffs; it is red, medium-grained and contains quartz, albite, microcline, muscovite and biotite, with accessory apatite, pyrite, chalcopyrite, rutile, ilmenite, monazite and zircon. The feldspars are strongly sericitised and the quartz shows undulose extinction. It also contains abundant, elongate, orientated xenoliths of metasediment. The Bunstane granite can only be accessed by boat and was not sampled. The outer granites are considered to be part of the SHSC on the basis of their close spatial and symmetrical relationship to the inner sequence and the similar petrography and age (Mark et al. 2019) of the Burnbanks granite to the inner sequence.

\subsection{The inner sequence}

2.3.1. Breccia. The presence of breccia bodies is unique amongst the Ordovician granites of NE Scotland. They are found as three main masses in the northern, central and southern parts of the Souter Head complex (Fig. 1). The southern outer contact is steep and faulted against the Bunstane granite. Large ( $20 \mathrm{~m}$-scale), rotated blocks of metasediment form a marginal zone that extends for about $100 \mathrm{~m}$, separating the granite from a finer-grained breccia. The northern outer contact against the Burnbanks granite is sharp and steep and can be accessed in Burnbanks Haven. Contacts between breccia and the inner granites are typically straight, steep and faulted. However, in places, the original contacts are preserved (e.g., NJ 9620 0182) and show continuation 


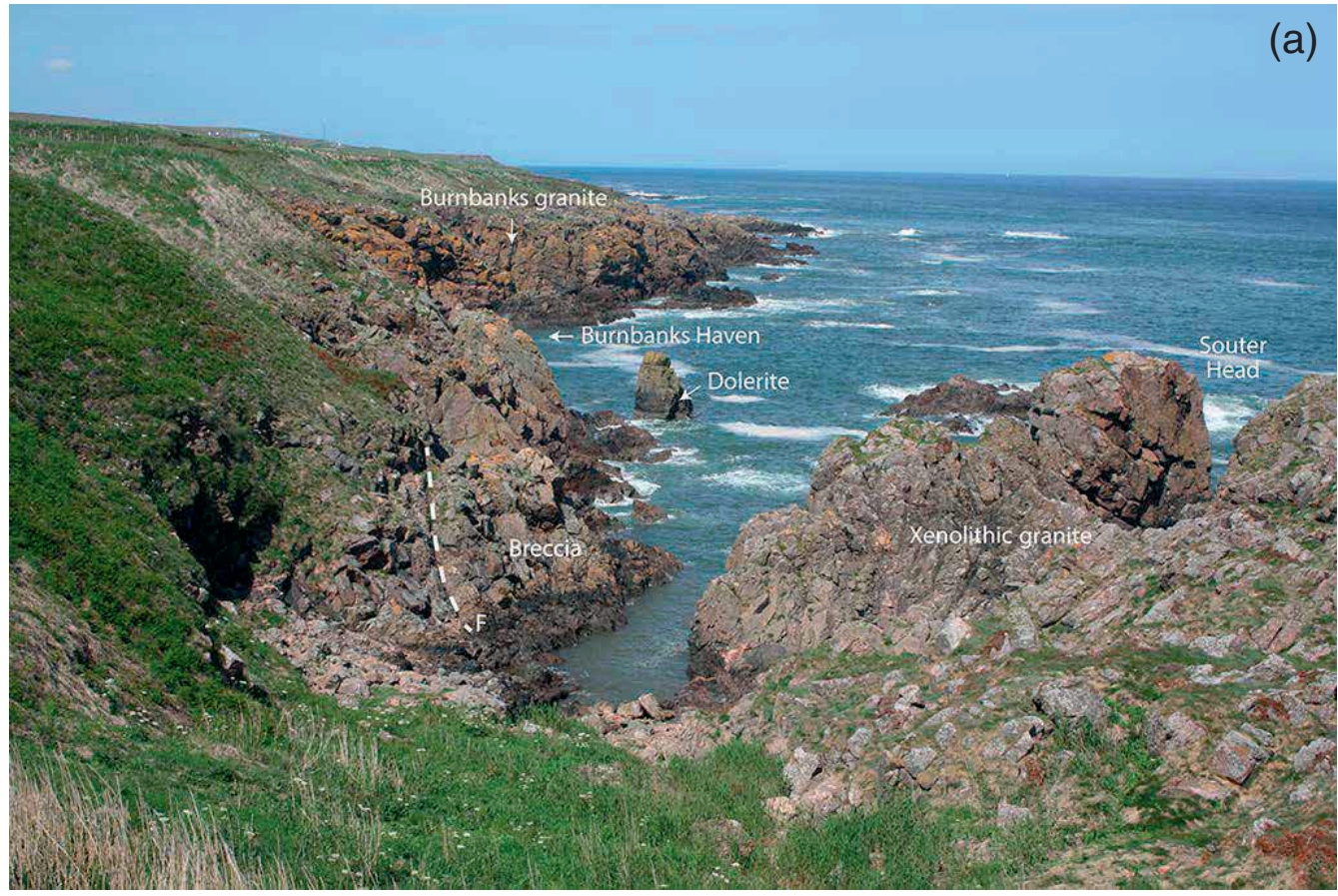

(b)

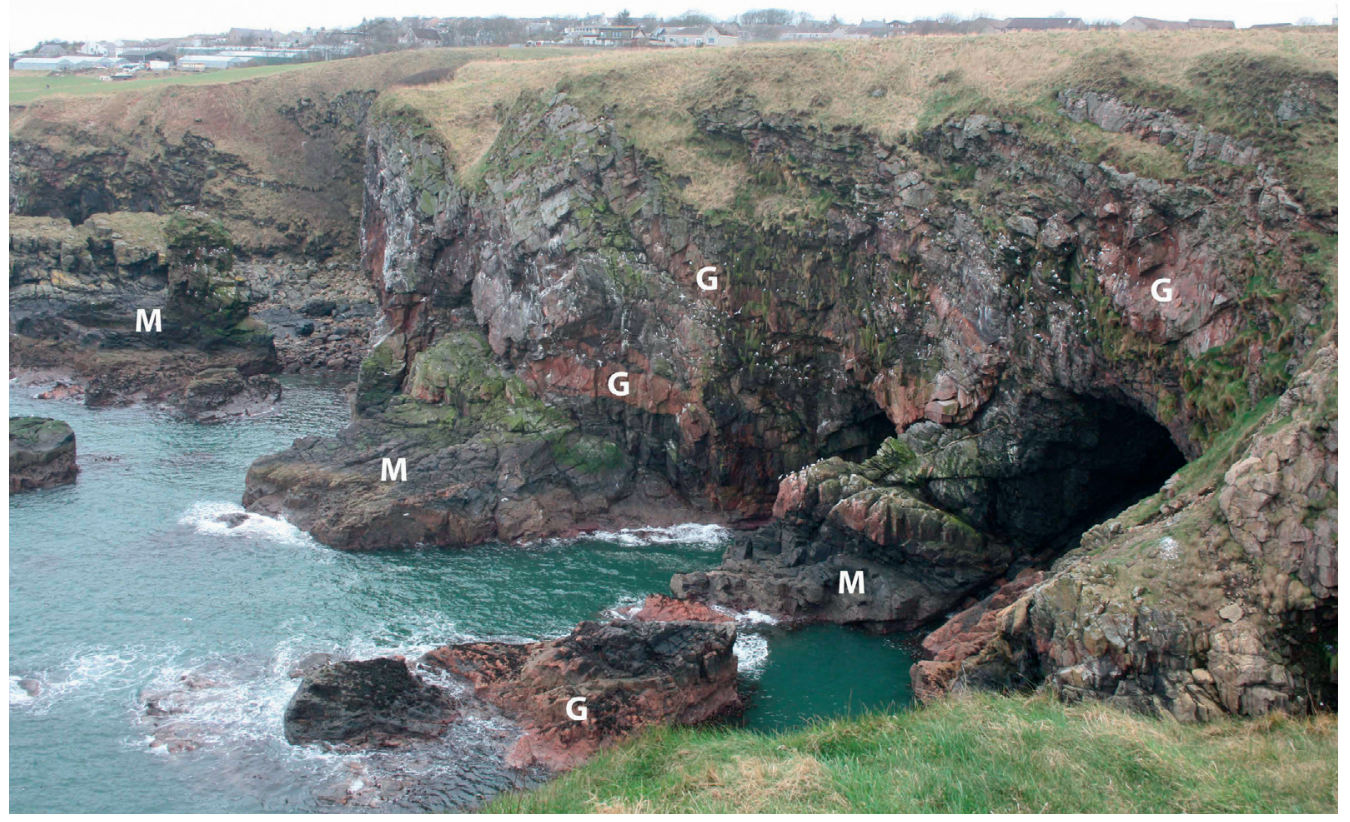

Figure 2 (a) View northwards from Souter Head to Burnbanks Haven. Outcrops of xenolithic granite, breccia, Burnbanks granite and a dolerite pillar can be seen. Inlet in foreground contains a dolerite dyke (see Fig. 1 for detailed geology). (b) Intrusive contact between pink outer Bunstane granite (G) and grey Dalradian metasediment (M). The granite sheets are generally concordant with the dominant fabric in the metasediments. Cove village is in the distance. (c) Breccia composed of randomly orientated metasediment clasts (M) with granite matrix (G). Later quartz (Q) infilling cavities and fractures. (d) Breccia (B) composed mainly of metasediment clasts with rare rounded granite clast $(\mathrm{G})$ cut by pink quartz porphyry dyke (P). (e) Breccia (B) cut by pink felsite dyke $c a .5 \mathrm{~m}$ thick (F). Note large raft of metasediment (MR) (Fig. 1, NJ 0190 9625). (f) Pink xenolithic granite. Xenoliths of grey partially digested metasediment. (g) Pegmatite dyke (pink mineral $K$-feldspar) cutting inner non-xenolithic granite and both faulted against breccia. (h) Faulted contact between breccia and non-xenolithic granite intruded by quartz porphyry. Early linear alteration zone with quartz veins cutting granite from left to right. All cut by late molybdenite-bearing quartz veins (QM) and associated alteration from top to bottom centre. Rounded pink cores of granite and porphyry upstanding relative to grey altered rock. Quartz vein in (j) is continuation of vein at top centre. (i) Explanatory sketch for (h). (j) Molybdenite-bearing group 2 quartz vein cutting breccia (B) looking S. Inner non-xenolithic granite in background $(G)$ (marked in Fig. 3). (h) shows a continuation of this vein to the south. $(\mathrm{k})$ Linear alteration zone with quartz veins $(\mathrm{Q})$ in non-xenolithic granite faulted against breccia (B). Fresh granite (FG) cores upstanding and surrounded by altered granite (AG). 


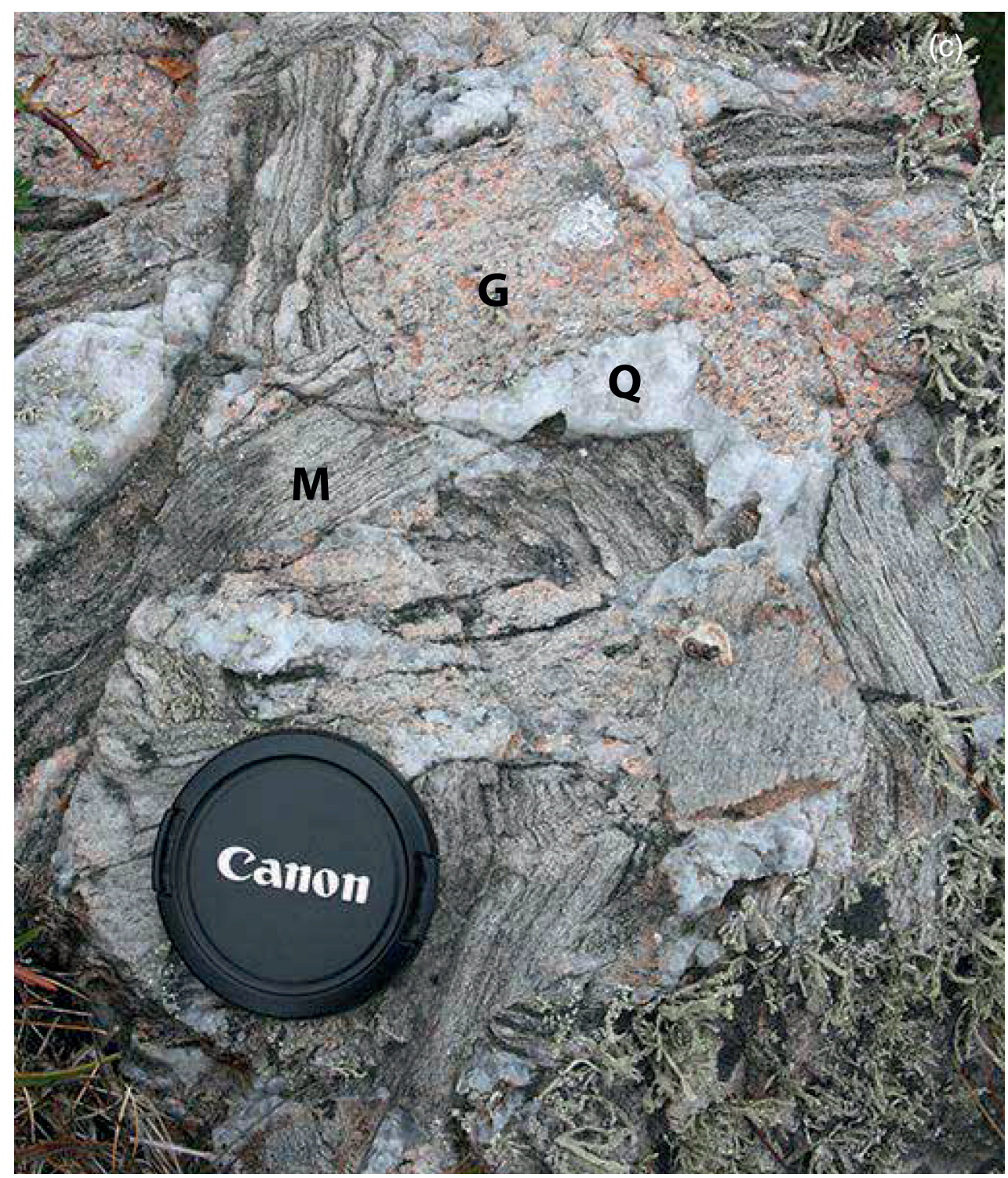

(d)

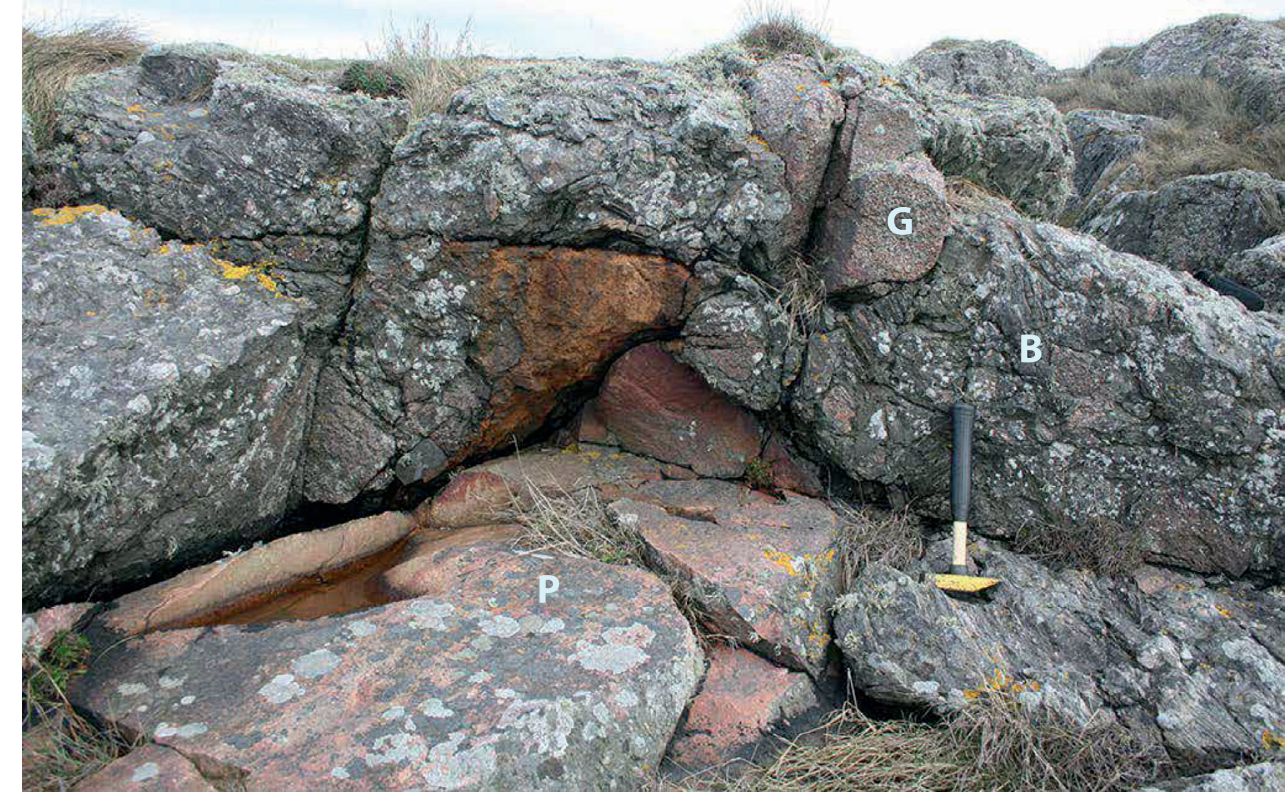

Figure 2 (Continued) 

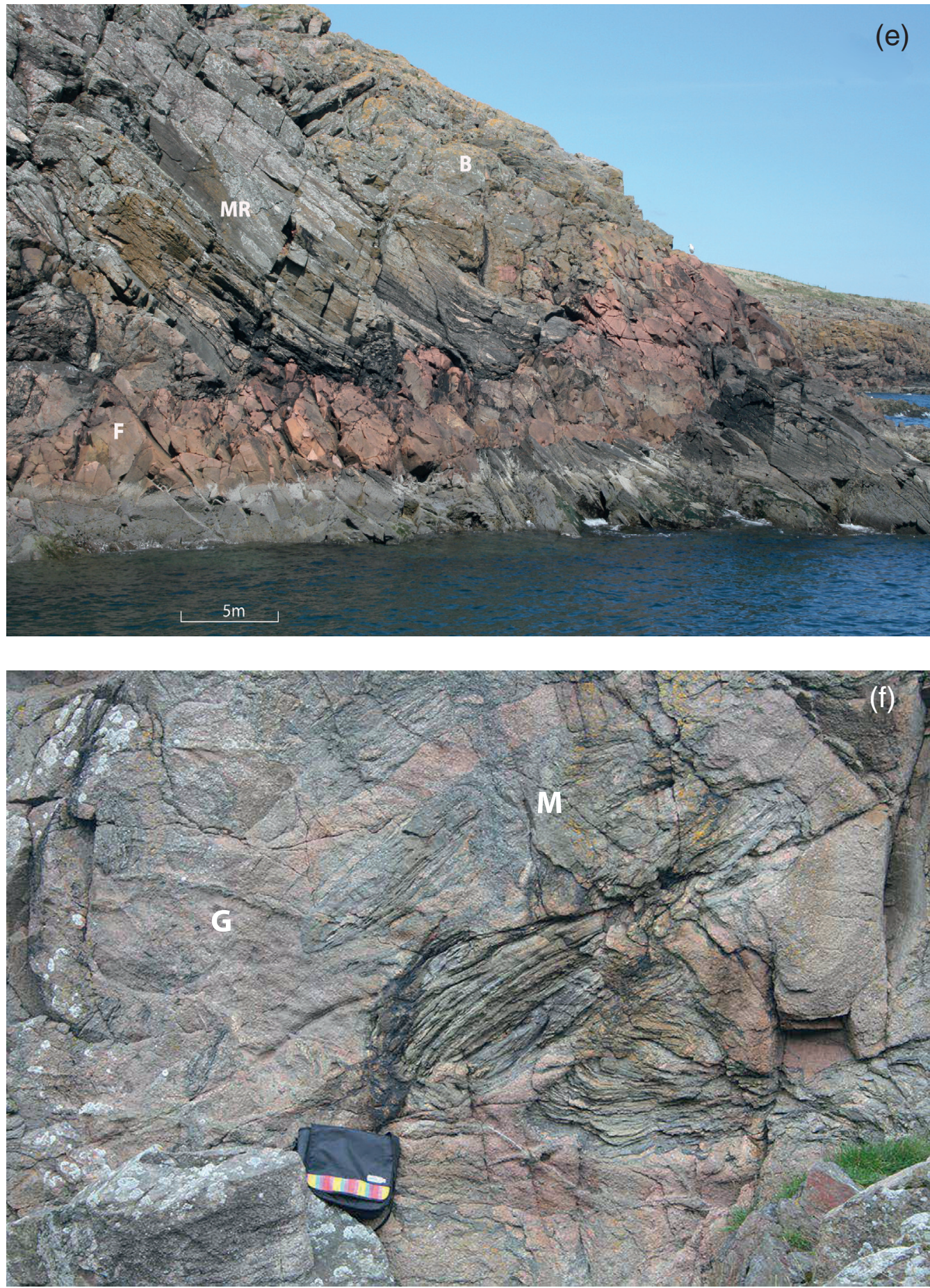

Figure 2 (Continued)

(1-5 m-scale) between inner granite and the granite matrix of the breccia, demonstrating that these granites intrude and postdate the breccia.

The breccia clasts are mainly semi-pelite, with rare (occasionally foliated) granite, amphibolite and vein quartz (Figs 2c, d). Clasts are typically angular with a few rounded clasts of granite, and poorly sorted. Most are in the 10$20 \mathrm{~cm}$-scale, but clasts up to $1 \mathrm{~m}$ are common and there are a few larger rafts of metasediment up to $30 \mathrm{~m}$ across (Figs 1, 2e). The orientation of the composite fabric in the metasediment and the foliation in granite clasts is typically random. In places, elongated clasts (e.g., amphibolite) show preferred orientation.

In the southern part of the complex the breccia is mainly clast-supported, whereas in the northern part the breccia is often matrix supported. Here the matrix consists of granite or pegmatite or quartz and contains rare miarolitic cavities with pyrite, calcite and molybdenite (Porteous 1973).

The breccia is interpreted as forming by the explosive release of volatiles from an underlying magma chamber, which shattered the country rock, as evidenced by rotated angular and rounded clasts. The presence of granite matrix in places suggests the bottom of the breccia column is exposed. Such breccias are classified as igneous cemented breccias or intrusion breccias and are common in subvolcanic stocks forming at levels in the range 1-10 km (Sillitoe 1985; Seedorf et al. 2005).

2.3.2. The inner granites. These are found as two masses separated by breccia (Fig. 1). The northern mass contains a weak and patchy foliation and abundant xenoliths, and is 

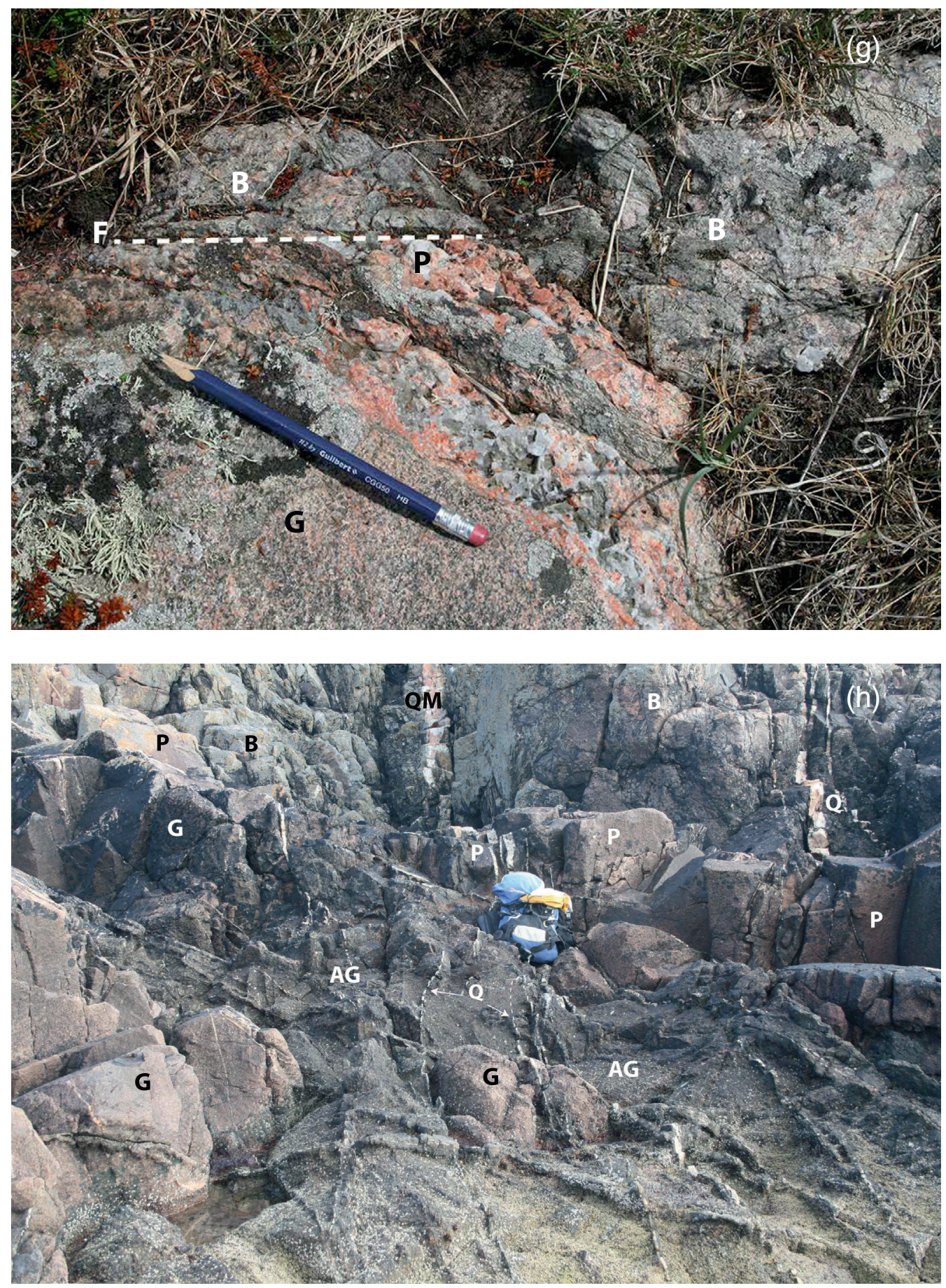

Figure 2 (Continued)

interpreted as a contact facies (Fig. 2f). The foliation is defined by biotite, which is enclosed by other minerals displaying an igneous texture and is interpreted as a magmatic foliation (Paterson et al. 1989). The southern block lacks both foliation and xenoliths. Marked variation in foliation occurs across EW structures in the northern mass (e.g., NJ 9617 0185) and may reflect later rotation along these structures. Xenoliths are mainly composed of semi-pelite with rare amphibolite. They range up to $20 \mathrm{~m}$ in diameter with variable shape and degree of assimilation. The density of xenoliths decreases towards the southern contact.

The granites are red, medium-grained and composed of quartz, showing weak undulose extinction, oligoclase, orthoclase, muscovite and biotite. There is also moderate sericitisation of feldspar and weak chloritisation of biotite. Accessory minerals include apatite, zircon, monazite, garnet and magnetite. The southern granite mass also contains finely disseminated pyrite (with inclusions of pyrrhotite and galena) and microcavities containing epidote and barite. The presence of muscovite and garnet indicates that these granites are strongly peraluminous.

2.3.3. Pegmatite. Pegmatites are unfoliated and composed of quartz, red $K$-feldspar, muscovite and biotite. They occur as small 1-5 m-scale irregular bodies and lenses, and as linear veins up to $90 \mathrm{~cm}$ wide that can be traced for up to $70 \mathrm{~m}$ along strike (Figs 1, 2g). The veins strike between N-S and NNESSW and are mainly found cutting the inner granites, whereas the irregular bodies typically occur in breccia. 

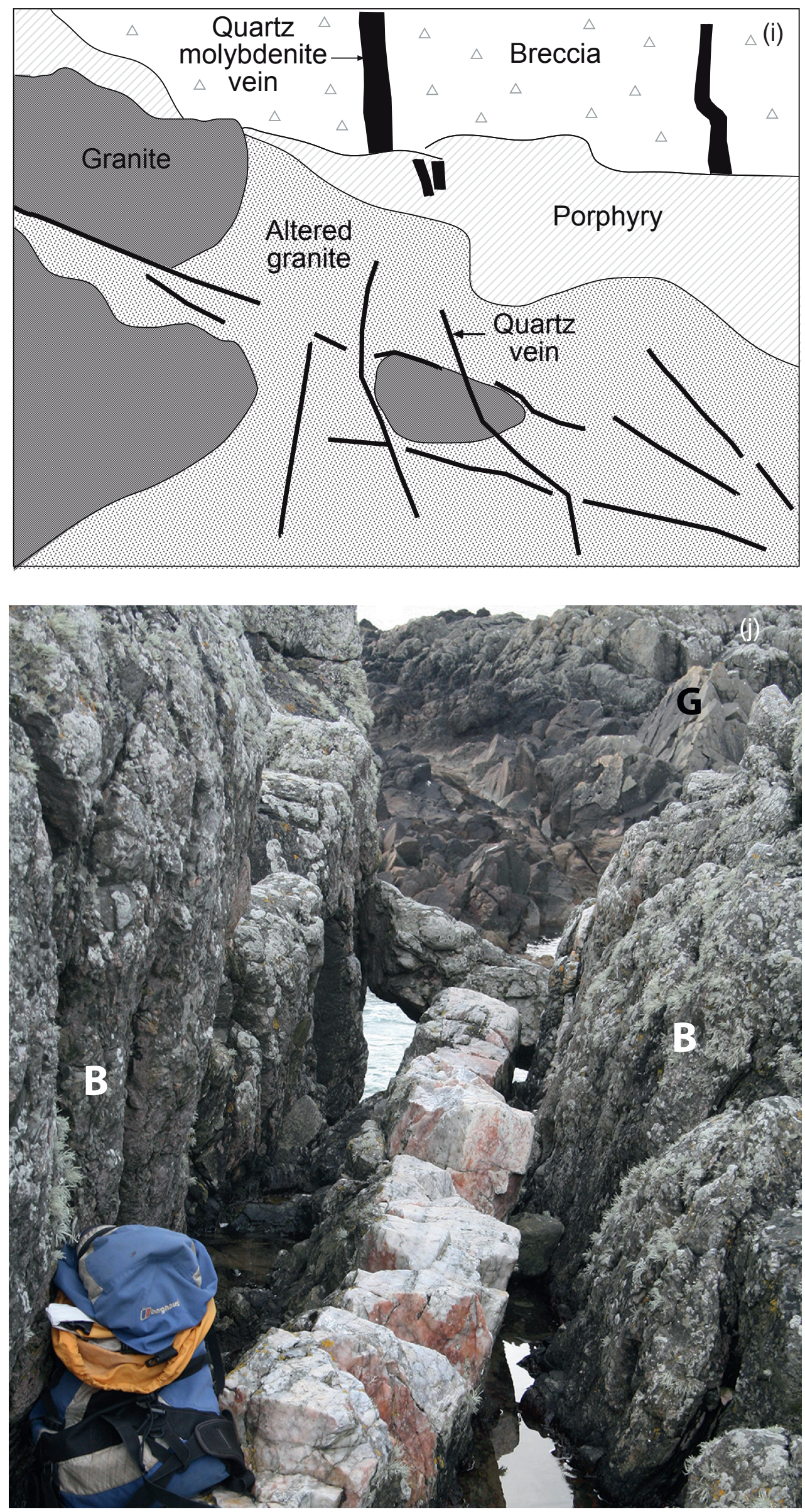

Figure 2 (Continued) 


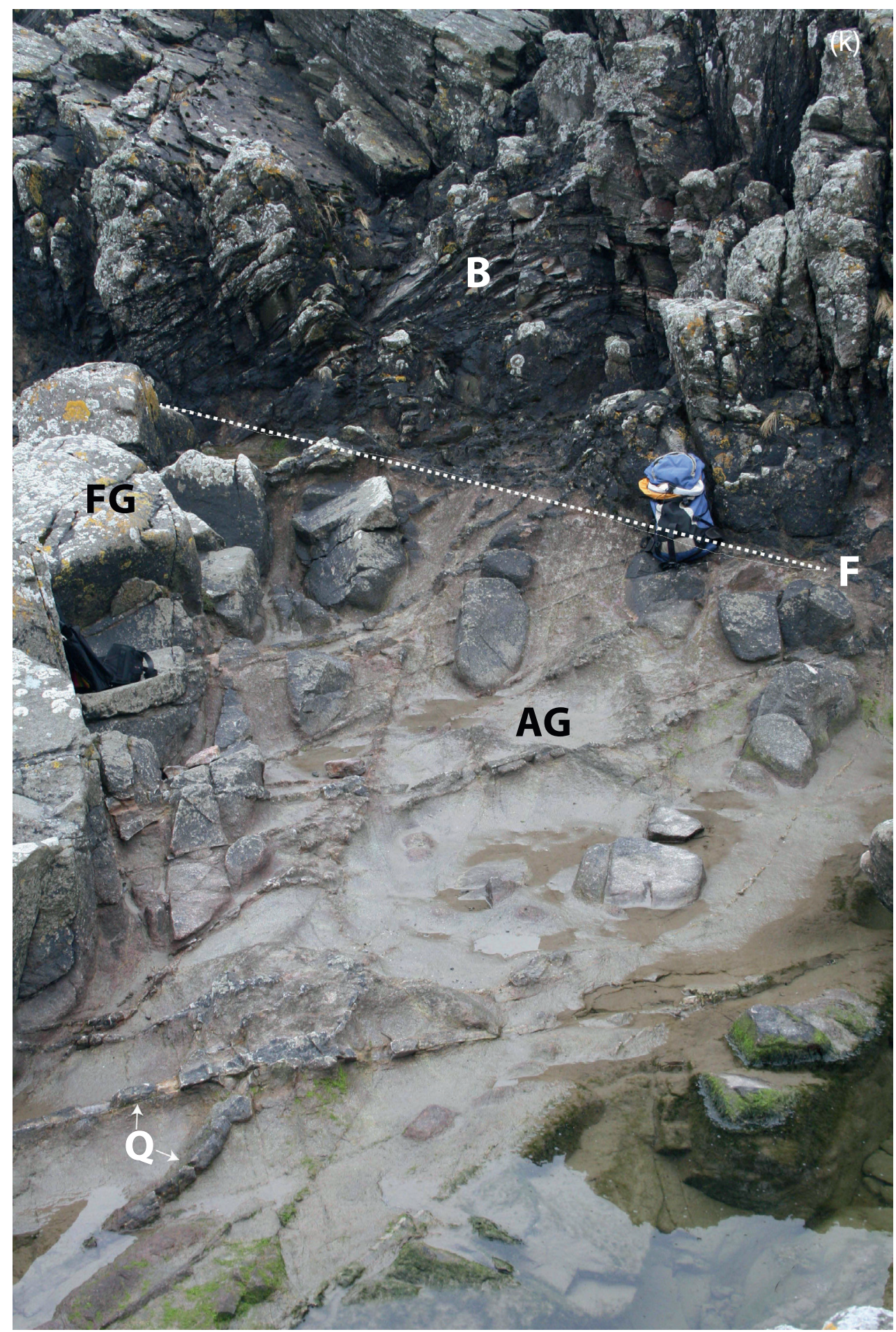

Figure 2 (Continued)

2.3.4. Quartz porphyry. Red quartz porphyry is mainly found cutting breccia as linear and anastomosing dykes (up to $1.5 \mathrm{~m}$ wide) with a predominant NW-SE orientation (Fig. 2d). It is essentially restricted to the central breccia body. In one locality (NJ 9616 0173) the quartz porphyry intrudes along the faulted contact between non-xenolithic granite, pegmatite and breccia, and thus postdates all three (Figs 1, 2h, i). The phenocrysts are mainly quartz (up to $2 \mathrm{~mm}$ ) with undulose extinction, microcline and albite (both up to $0.5 \mathrm{~mm})$, with small amounts $(<1 \%)$ of biotite and muscovite. The matrix contains the same minerals, but muscovite is more common, together with sparse manganese-iron garnet. There are also trace amounts of biotite, monazite, xenotime and zircon.

2.3.5. Felsite. Red felsite occurs as dykes reaching up to $5 \mathrm{~m}$ thick (Fig. 2e), which are cut by N-S vertical and easterly dipping quartz veins. The main minerals in a fine-grained groundmass are quartz, sodic plagioclase, $K$-feldspar and minor muscovite. $K$-feldspar occurs as sector-zoned microphenocrysts and also in lace-textured, radiating intergrowths with quartz. There are accessory amounts of monazite, apatite, rutile and zircon. Pyrite, sericite and kaolinite alteration of feldspar are locally common. Some of the coarser muscovite may be primary. The felsites are post-breccia and pre-quartz 


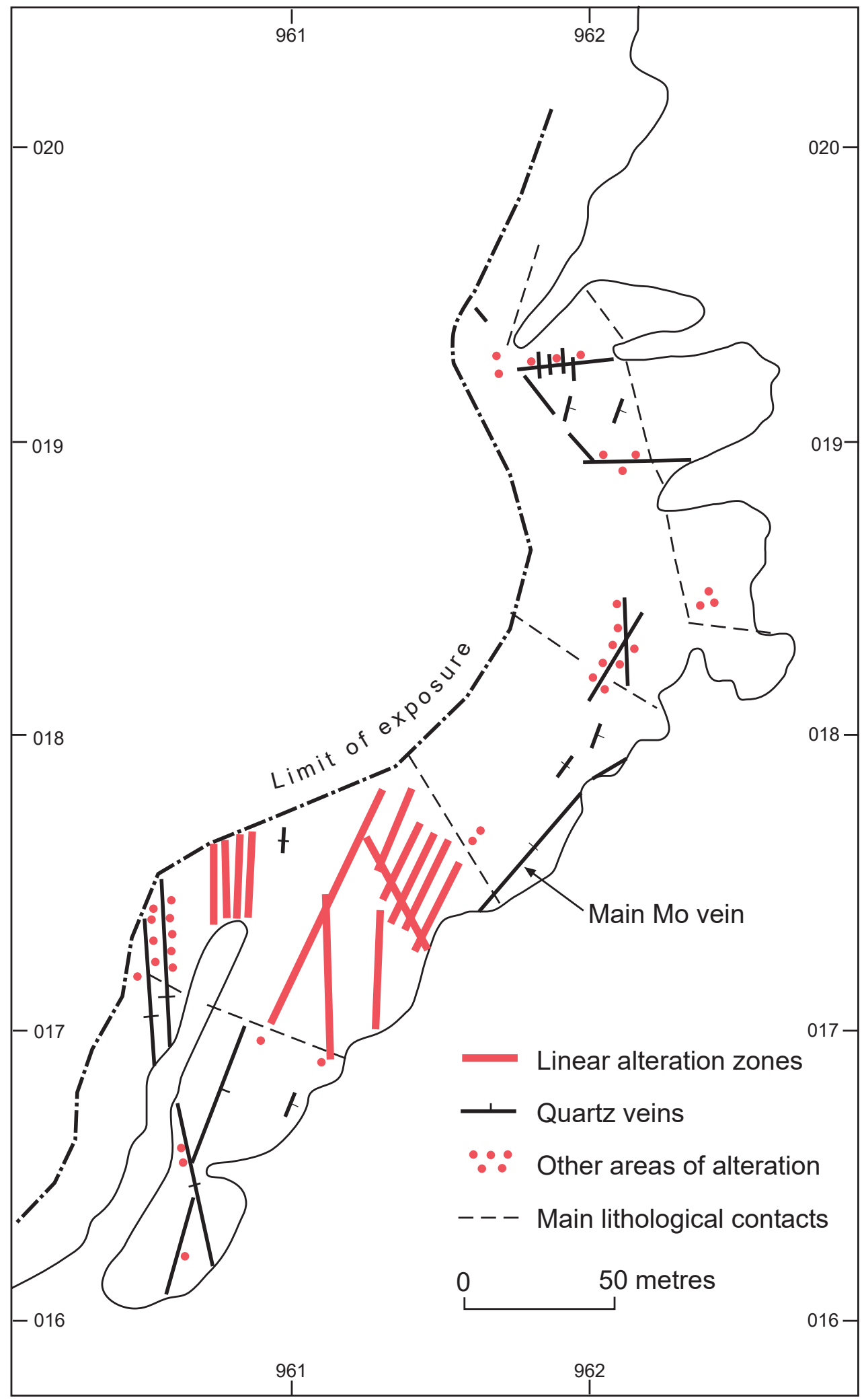

Figure 3 Distribution of hydrothermal alteration and main quartz veins in the SHSC.

veins and, thus, of a comparable age to the SHSC. However, felsites have geochemical differences (see Section 4.1) and occur outwith the complex (e.g., Porteous 1973) and may be unrelated to it.

2.3.6. Dolerite. There are small exposures of dolerite dykes (up to $5 \mathrm{~m}$ wide) throughout the complex. They cut all the main rock types and felsite, lack quartz veins and are not significantly hydrothermally altered. The dykes have similar NNE-SSW and E-W orientations to dolerite dykes outcropping along the coast near Souter Head and to Carboniferous quartz dolerite dykes found elsewhere in Aberdeenshire (Stephenson \& Gould 1995). They are considered to be Carboniferous quartz dolerites (Kneller \& Gillen 1987) and are not considered further herein.

2.3.7. Quartz veins. Quartz veins and attendant hydrothermal alteration are an important component of the complex (Fig. 3). All the main rock units and felsite and quartz porphyry are cut by quartz veins and affected by hydrothermal alteration to a varying extent. The quartz veins are generally straight-sided, massive and lack vugs, and they fall into 


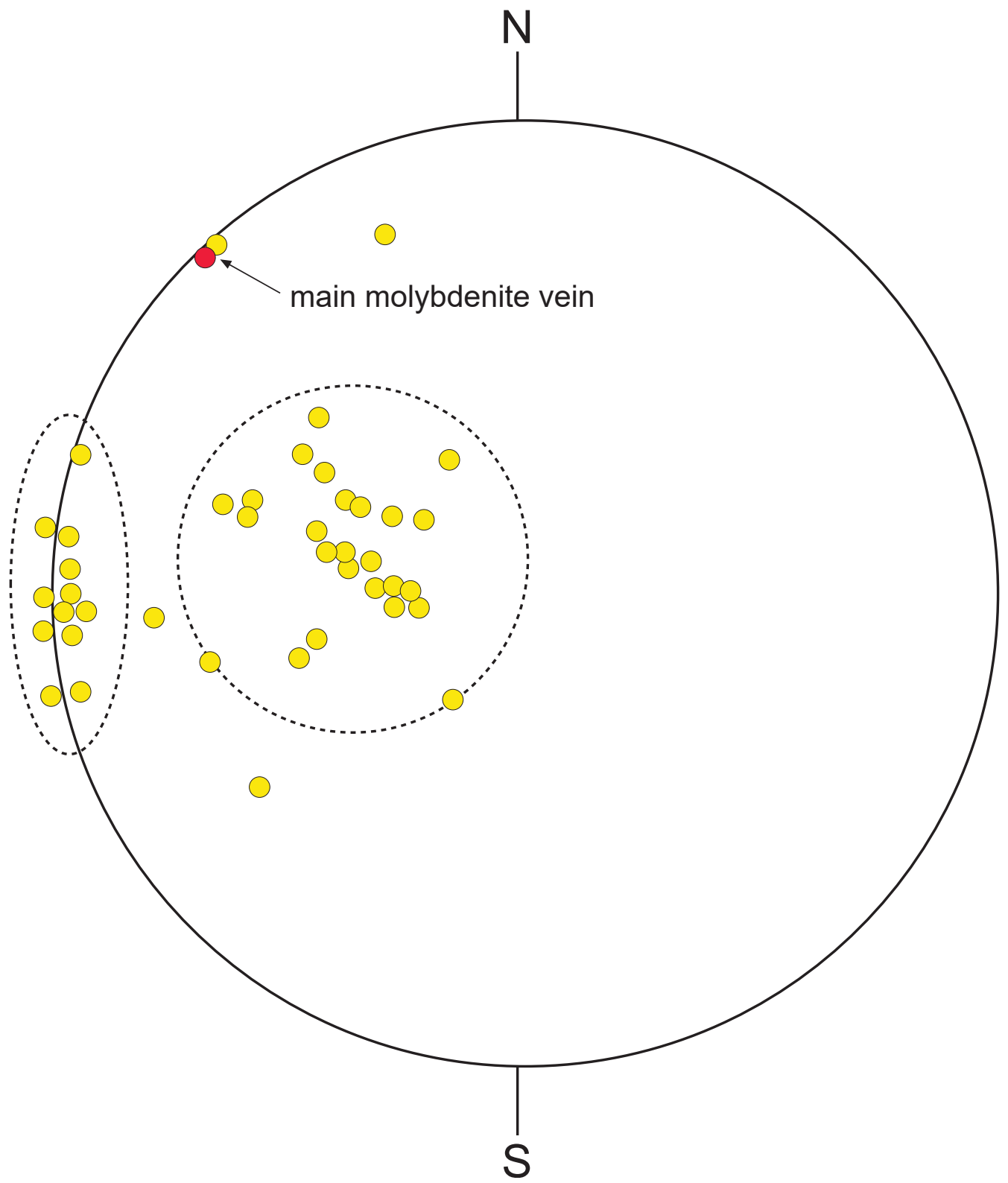

Figure 4 Orientation of group 2 quartz veins. Most fall into two sets: N-S vertical and $\mathrm{N}-\mathrm{S}$ dipping E.

two main groups. The earliest (group 1) comprises veins occurring within linear alteration zones, principally cutting the non-xenolithic granite and predating the quartz porphyry. These veins will be discussed in Section 2.3.8. The second (group 2) and most abundant consists of veins, which postdate the porphyry and cut the main rock units and the contacts between them (Figs $2 \mathrm{~h}-\mathrm{j}$ ). This second group consists mainly of two sets of $\mathrm{N}-\mathrm{S}$-striking veins, one vertical and the other dipping easterly at a shallow angle, a minor E-W-orientated set and two NE-SW striking veins (Fig. 4). The order of emplacement from oldest to youngest is (1) N-S vertical; (2) $\mathrm{N}-\mathrm{S}$ easterly dipping; and (3) E-W. The two N-S-orientated sets are best developed cutting the granites where, for example, ten easterly dipping veins $(1-2 \mathrm{~cm}$ thick) were recorded in a $100 \mathrm{~m}$ traverse across the non-xenolithic granite.

The $\mathrm{N}-\mathrm{S}$ vertical veins are up to $50 \mathrm{~cm}$ thick and the largest can be traced for at least $125 \mathrm{~m}$. They contain sparse $K$-feldspar and pyrite cubes. The N-S easterly dipping set are up to $20 \mathrm{~cm}$ thick and contain occasional pyrite-rich lenses. These veins cut all main rock units. The $\mathrm{E}-\mathrm{W}$ set is thin (up to $5 \mathrm{~cm}$ ) and contains quartz only. One of the NE-SW striking veins is $30 \mathrm{~cm}$ thick and contains thin margin-parallel bands and clusters of muscovite and molybdenite (Fig. 2j). It can be traced for over
$50 \mathrm{~m}$ and cuts breccia, non-xenolithic granite and quartz porphyry (Fig. 2h, i).

2.3.8. Hydrothermal alteration. This is widespread and linked to quartz veining (Fig. 3). The most intense alteration occurs in numerous linear vertical zones in the non-xenolithic granite associated with group 1 quartz veins (Fig. 2h, i, k). The zones are orientated $\mathrm{N}-\mathrm{S}$ and NNE-SSW, and are typically up to $4 \mathrm{~m}$ wide but are more extensive at intersections. They are characterised by stockwork veining, thin $\mathrm{cm}$-scale zone parallel vertical (group 1) quartz veins and intense argillic (kaolinite) alteration. In places, granite in the zones is intensely shattered so that only mineral fragments, mainly quartz and micas, can be recognised. All feldspar has been altered to kaolinite, which dominates the fine-grained matrix. Typically, the alteration zones are truncated at faulted breccia contacts (Fig. 2k), but in places the largest zones extend for a few metres into the breccia. The alteration zones associated with the group 2 quartz veins are narrow (up to $1 \mathrm{~m}$ ), patchy, less intense and lack stockwork veining. The main alteration mineral is sericite rather than kaolinite. Away from all veins, weak alteration is pervasive and widespread and comprises sericite, kaolinite, chlorite, pyrite, epidote and barite. 
2.3.9. Minerals of economic interest. Molybdenite is the only mineral of potential economic interest, found mainly in quartz veins, with minor amounts in the breccia accompanying calcite within miarolitic cavities (Porteous 1973) and as coatings on fractures. Quartz vein-hosted molybdenite occurs with pyrite in $\mathrm{N}-\mathrm{S}$ easterly dipping veins and in thin veins in NNE-SSW alteration zones, but is most abundant in the single NE-SW-striking vein (Fig. 2j). Molybdenite is confined to the central part of the complex.

2.3.10. Field relations between the breccia and inner granites. These have proved controversial in the past and are critically important for reconstructing the events leading to the formation of the SHSC. The non-xenolithic granite has been interpreted as a large block in the breccia (Munro 1986) or as an intrusive body extending into the breccia (Porteous 1973; Lowry 1991). The presence of transitional contacts between granite and the granite matrix of the breccia supports the latter interpretation. The occurrence of a weak and patchy foliation in the xenolithic granite, which varies in orientation across E-W-trending linear structures, led Porteous (1973) and Lowry (1991) to interpret this granite mass as three large clasts hosted by breccia (i.e., the breccia postdates the granite). However, this is not supported by transitional contacts (recognised by Lowry 1991) (e.g., NJ 9620 0182), which indicate that the granites are intruding and, therefore, postdate the breccia. The rotation of the foliation across structures may be due to subsequent deformation that preceded pegmatite emplacement.

\section{Structure}

Although the contacts of the outer granites with the country rocks are intrusive (Fig. 2b), the internal contacts between the dominant rock types, granite and breccia are steep and generally faulted. The complex is strongly fractured along two main directions, $\mathrm{E}-\mathrm{W}$ and $\mathrm{N}-\mathrm{S}$, best seen in the granites. The coastal topography is strongly influenced by these and other fracture sets, e.g., the well-defined narrow NNE-SSW inlets and the steep E-W faces of the inlets forming Souter Head itself (Figs 1, 2a). The various dykes, sills and quartz veins show varying orientations. Thus, pegmatites are $\mathrm{N}-\mathrm{S}$ to NNE-SSW, porphyries are NW-SE and E-W, felsites are $\mathrm{N}-\mathrm{S}$ and NW-SE, dolerite dykes NNE-SSW and E-W, linear alteration zones $\mathrm{N}-\mathrm{S}$ and NNE-SSW and quartz veins mainly $\mathrm{N}-\mathrm{S}$. These variations (dolerite dykes excepted) reflect changing stress regimes possibly linked to rapid exhumation (Mark et al. 2019).

In the absence of slickensides and offset structures, the sense and amount of movement along the faults cannot be determined. An exception is a right lateral wrench fault (NJ 96050172 ) that displaces a vertical felsite dyke by about $20 \mathrm{~m}$ and is sealed by a N-S quartz vein (Fig. 1). All significant movement along granite-breccia contacts ceased before emplacement of quartz porphyry and group 2 quartz veins. These show limited deformation and, therefore, most of the structural features in the complex are of Ordovician age. PostOrdovician deformation involved reactivation of some NNE and EW structures during the Permo-Carboniferous and emplacement of dolerite dykes.

\section{Geochemistry}

The purposes of the geochemical analysis were: (1) to assist in the description and classification of this magmatichydrothermal system; (2) combined with field data, to assess the economic potential of the SHSC; and (3) to compare the granitic rocks in the SHSC with others in the Grampian terrane to assess the potential of the region for further mineralisation of this type. A representative sample of the various rock types from the inner sequence, together with hydrothermally altered granite and quartz veins, were analysed for major elements, rare-earth elements (REEs) and trace elements (Table 1). A composite sample of chips from outcrops of the breccia-granite matrix with hydrothermal quartz was analysed for trace elements only.

\subsection{Fresh rock}

All the intrusives are silica- and alkali-rich, with silicon dioxide $\left(\mathrm{SiO}_{2}\right)$ and potassium oxide $\left(\mathrm{K}_{2} \mathrm{O}\right)+$ sodium oxide $\left(\mathrm{Na}_{2} \mathrm{O}\right)$ values in the ranges $70-78 \%$ and $6-9 \%$, respectively (Table 1 ). Apart from aluminium oxide $\left(\mathrm{Al}_{2} \mathrm{O}_{3}\right)(13.7-15.1 \%)$, no other major oxide exceeds $3.07 \%$. The Souter Head suite is all strongly peraluminous (i.e., $\mathrm{Al}_{2} \mathrm{O}_{3} / \mathrm{CaO}+\mathrm{Na}_{2} \mathrm{O}+\mathrm{K}_{2} \mathrm{O}>1.1$ ).

Multi-element variation patterns for the inner granites show typical granitic characteristics when normalised against mantle compositions, i.e., a background of increasing rightto-left enrichment and the commonly observed troughs for niobium $(\mathrm{Nb})$, strontium $(\mathrm{Sr})$, phosphorus $(\mathrm{P})$ and titanium (Ti) (Fig. 5a, b). The latter probably reflect fractionation by mineral phases such as plagioclase, biotite and apatite at some time during the history of the magma or of its source (Halliday et al. 1981; Halliday \& Stephens 1984; Tarney \& Jones 1994). When the same suite of elements is normalised against bulk crust (not shown) values lie close to 1.0 (range $0.3-4.4$, mean 1.7; bulk crust values from Rudnick \& Gao 2003).

All units show enrichment in light rare-earth elements (LREE) and the strongest enrichments occur in the inner granites, probably reflecting the presence of more apatite and monazite (highest phosphorus pentoxide $\left(\mathrm{P}_{2} \mathrm{O}_{5}\right)$ values; Table 1; Fig. 5c).

The multi-element pattern of the inner granites is similar to that of the nearby Ordovician Aberdeen granite and different to those of the Late Caledonian granites of the eastern Grampians, which have more pronounced troughs (Fig. 5d).

Pegmatite is more depleted in thorium (Th), uranium (U), $\mathrm{Nb}$, LREE, Sr and zirconium ( $\mathrm{Zr}$ ) than the inner granites, probably reflecting increased fractionation of plagioclase, biotite, rutile, phosphates and zircon (Fig. 5a, c).

The most obvious differences in the suite are between the youngest member, the porphyry, and the other members. It shows marked troughs in barium $(\mathrm{Ba}), \mathrm{Sr}$, europium $(\mathrm{Eu})$ and $\mathrm{Ti}$, and a flatter REE profile probably representing further fractionation of feldspar, rutile and phosphates (Fig. 5b, c). The porphyry contains the highest levels of sodium $(\mathrm{Na})$, rubidium $(\mathrm{Rb})$ and heavy rare-earth elements (possibly hosted by groundmass garnet).

The felsite pattern is most like the inner granites, but is smoother and has only one strong trough (Ti) and the REE pattern is flatter, suggesting a different history (Fig. 5b, c). These geochemical differences, together with the regional distribution of felsite, suggest that, while of a similar age (see Section 2.3.5), it is not genetically related to the SHSC. Other felsites in the region, whose age is poorly constrained, may be Ordovician also.

\subsection{Mineralisation and alteration}

Pyrite lenses in the easterly dipping quartz veins contain anomalous quantities of As (109 ppm), Bi $(900 \mathrm{ppm})$, Mo (4150 ppm) and $\mathrm{Au}(60 \mathrm{ppb})$ (Table 1). However, the only heavy metal found in anomalous quantities in the main quartz-molybdenite vein and the breccia-granite matrix is 
Table 1 Souter Head major elements, rare-earth elements (REEs) and trace elements (all ppm except Au ppb and S \%). Abbreviations: NXG = non-xenolithic granite; $\mathrm{XG}=$ xenolithic granite; Peg = pegmatite; $\mathrm{QP}=$ quartz porphyry; Dol = dolerite; $\mathrm{S}$ vein $=$ sulphide lens in Group 2 quartz vein; Mo vein = main molybdenite vein; AltNXG = granite from linear alteration zone; Bx matrix = igneous matrix from intrusion breccia (analysed for trace elements only); N/A = not analysed. Selected bulk crust values from Rudnick \& Gao (2003) in ppm for As (2.5), Bi (0.18), $\mathrm{Mo}$ (0.8), $\mathrm{Pb}(11)$ and in ppb for $\mathrm{Au}$ (1.3). Analyses by ALS Minerals, Loughrea, Co. Galway.

\begin{tabular}{|c|c|c|c|c|c|c|c|c|c|c|}
\hline & $\begin{array}{c}\text { NXG } \\
\text { SH4 }\end{array}$ & $\begin{array}{c}\text { XG } \\
\text { SH11 }\end{array}$ & $\begin{array}{l}\text { Peg } \\
\text { SH9 }\end{array}$ & $\begin{array}{c}\text { QP } \\
\text { SH5 }\end{array}$ & $\begin{array}{c}\text { Felsite } \\
\text { SH3 }\end{array}$ & $\begin{array}{c}\text { Dolerite } \\
\text { SH6 }\end{array}$ & $\begin{array}{l}\text { S vein } \\
\text { SH1 B }\end{array}$ & $\begin{array}{c}\text { Mo vein } \\
\text { SH7 }\end{array}$ & $\begin{array}{c}\text { Alt NXG } \\
\text { SH2 B }\end{array}$ & $\begin{array}{c}\text { Bx matrix } \\
\text { SH } 22\end{array}$ \\
\hline \multicolumn{11}{|c|}{ Major elements } \\
\hline $\mathrm{SiO}_{2}$ & 70.1 & 71.9 & 71.8 & 71.1 & 77.9 & 48.6 & 72.7 & 98.9 & 74.7 & \\
\hline $\mathrm{TiO}_{2}$ & 0.37 & 0.38 & 0.13 & 0.06 & 0.10 & 3.03 & 0.06 & 0.02 & 0.37 & \\
\hline $\mathrm{Al}_{2} \mathrm{O}_{3}$ & 14.65 & 14.25 & 15.1 & 14.9 & 13.7 & 12.5 & 2.34 & 0.44 & 14.85 & \\
\hline $\mathrm{Fe}_{2} \mathrm{O}_{3}(\mathrm{~T})$ & 2.64 & 3.07 & 1.40 & 1.02 & 1.64 & 14.85 & 15.10 & 0.48 & 2.20 & \\
\hline $\mathrm{MnO}$ & 0.04 & 0.02 & 0.01 & 0.03 & 0.10 & 0.17 & 0.01 & $<0.01$ & 0.02 & \\
\hline $\mathrm{MgO}$ & 0.56 & 0.48 & 0.22 & 0.10 & 0.21 & 5.09 & 0.12 & 0.03 & 0.54 & \\
\hline $\mathrm{CaO}$ & 1.60 & 0.75 & 0.51 & 0.30 & 0.69 & 8.30 & 0.01 & 0.04 & 0.33 & \\
\hline $\mathrm{Na}_{2} \mathrm{O}$ & 3.17 & 2.50 & 2.30 & 4.45 & 4.37 & 2.47 & 0.05 & 0.02 & 0.43 & \\
\hline $\mathrm{K}_{2} \mathrm{O}$ & 3.65 & 5.53 & 5.53 & 4.57 & 1.64 & 0.61 & 0.78 & 0.13 & 4.15 & \\
\hline $\mathrm{P}_{2} \mathrm{O}_{5}$ & 0.18 & 0.16 & 0.14 & 0.05 & 0.05 & 0.28 & 0.03 & 0.01 & 0.18 & \\
\hline$L O I$ & 1.05 & 1.20 & 1.53 & 0.78 & 1.47 & 1.90 & 8.91 & 0.50 & 3.52 & \\
\hline Total & 98.01 & 100.24 & 98.67 & 97.36 & 101.87 & 97.8 & 100.11 & 100.57 & 101.29 & \\
\hline \multicolumn{11}{|l|}{ REE } \\
\hline $\mathrm{La}$ & 77.8 & 66.3 & 5.7 & 6 & 18.7 & 21.4 & 8 & 0.5 & 49.7 & \\
\hline $\mathrm{Ce}$ & 142 & 124.5 & 9.8 & 13.9 & 38.9 & 48.3 & 14.7 & $<0.5$ & 90.3 & \\
\hline $\operatorname{Pr}$ & 15.55 & 14.2 & 1.28 & 1.7 & 4.82 & 6.75 & 1.58 & 0.04 & 9.88 & \\
\hline $\mathrm{Nd}$ & 55.9 & 52.8 & 5.1 & 6.7 & 17.1 & 30.8 & 5.4 & 0.1 & 37.2 & \\
\hline $\mathrm{Sm}$ & 7.99 & 7.97 & 1.1 & 2.41 & 3.68 & 7.01 & 0.83 & $<0.03$ & 6.1 & \\
\hline $\mathrm{Eu}$ & 1.36 & 1.52 & 0.61 & 0.09 & 0.72 & 2.5 & 0.16 & $<0.03$ & 1.07 & \\
\hline $\mathrm{Gd}$ & 5.44 & 5.34 & 1.63 & 2.56 & 3.36 & 8.36 & 0.51 & 0.06 & 3.78 & \\
\hline $\mathrm{Tb}$ & 0.67 & 0.6 & 0.33 & 0.6 & 0.56 & 1.15 & 0.03 & $<0.01$ & 0.48 & \\
\hline Dy & 2.93 & 2.84 & 2.8 & 3.93 & 3.42 & 7.57 & 0.23 & $<0.05$ & 2.56 & \\
\hline Но & 0.4 & 0.45 & 0.56 & 0.69 & 0.6 & 1.42 & 0.03 & $<0.01$ & 0.45 & \\
\hline $\mathrm{Er}$ & 0.9 & 1.26 & 1.79 & 1.97 & 1.65 & 3.74 & 0.09 & $<0.03$ & 1.11 & \\
\hline $\mathrm{Tm}$ & 0.05 & 0.11 & 0.26 & 0.26 & 0.22 & 0.58 & $<0.01$ & $<0.01$ & 0.1 & \\
\hline $\mathrm{Yb}$ & 0.92 & 0.85 & 1.89 & 2.19 & 1.5 & 3.28 & 0.13 & $<0.03$ & 1.1 & \\
\hline $\mathrm{Lu}$ & 0.09 & 0.15 & 0.27 & 0.27 & 0.24 & 0.56 & $<0.01$ & $<0.01$ & 0.17 & \\
\hline $\mathrm{Y}$ & 10.7 & 12.2 & 15.9 & 21 & 17.4 & 35.2 & 0.9 & $<0.5$ & 11.2 & \\
\hline \multicolumn{11}{|c|}{ Trace elements } \\
\hline $\mathrm{Ag}$ & $<0.5$ & $<0.5$ & $<0.5$ & $<0.5$ & $<0.5$ & $<0.5$ & 0.9 & $<0.5$ & $<0.5$ & $<0.5$ \\
\hline As & $<5$ & 5 & 8 & 6 & $<5$ & 16 & 109 & $<5$ & 31 & $<5$ \\
\hline $\mathrm{Au}$ & $<10$ & $\mathrm{~N} / \mathrm{A}$ & 10 & $<10$ & $<10$ & $<10$ & 60 & $<10$ & 10 & $<10$ \\
\hline $\mathrm{Ba}$ & 946 & 1475 & 1325 & 37 & 545 & 123 & 218 & 31 & 1195 & 450 \\
\hline $\mathrm{Be}$ & 3 & $\mathrm{~N} / \mathrm{A}$ & 4 & 3 & 4 & 1 & 6.5 & $<0.5$ & 2 & 2.6 \\
\hline $\mathrm{Bi}$ & 2 & $\mathrm{~N} / \mathrm{A}$ & $<2$ & $<2$ & 2 & $<2$ & 900 & $<2$ & $<2$ & $<2$ \\
\hline $\mathrm{Cd}$ & $<0.5$ & $<0.5$ & $<0.5$ & $<0.5$ & $<0.5$ & $<0.5$ & $<0.5$ & $<0.5$ & $<0.5$ & $<0.5$ \\
\hline $\mathrm{Co}$ & 4 & 3 & 1 & $<1$ & 1 & 46 & 2 & 1 & 3 & 4 \\
\hline $\mathrm{Cr}$ & 7 & $460 ?$ & 10 & 4 & 6 & 54 & 14 & 10 & 7 & 27 \\
\hline Cs & 2.4 & 2.1 & 1.1 & 2.2 & 0.5 & 0.5 & 1.5 & 0.04 & 3.5 & $\mathrm{~N} / \mathrm{A}$ \\
\hline $\mathrm{Cu}$ & 9 & 7 & 10 & 4 & 14 & 240 & 18 & 5 & 11 & 6 \\
\hline $\mathrm{Ga}$ & 23 & 18 & 15 & 25 & 21 & 24 & 6 & 2 & 22 & 20 \\
\hline Hf & 6.9 & 6.1 & 0.5 & 2.1 & 2.6 & 5.5 & 0.3 & $<0.2$ & 6.4 & $\mathrm{~N} / \mathrm{A}$ \\
\hline $\mathrm{Li}$ & 40 & 20 & $<10$ & $<10$ & $<10$ & 10 & 40 & 10 & 30 & $\mathrm{~N} / \mathrm{A}$ \\
\hline Mo & 4 & 6 & 4 & 1 & 2 & 1 & 4150 & 3790 & 14 & 41 \\
\hline $\mathrm{Ni}$ & 1 & 7 & 2 & $<1$ & 2 & 57 & 2 & $<1$ & 2 & 11 \\
\hline $\mathrm{Nb}$ & 35 & 22 & 13 & 38 & 21 & 19 & 5 & 1 & 31 & $\mathrm{~N} / \mathrm{A}$ \\
\hline $\mathrm{Pb}$ & 17 & 31 & 37 & 19 & 8 & 9 & 64 & 2 & 17 & 16 \\
\hline $\mathrm{Rb}$ & 118 & 147 & 102 & 197 & 47 & 15 & 49 & 6 & 125 & $\mathrm{~N} / \mathrm{A}$ \\
\hline $\mathrm{S}$ & 0.04 & $\mathrm{~N} / \mathrm{A}$ & 0.01 & $<0.01$ & 0.7 & 0.09 & 6.4 & 0.21 & 0.02 & 0.01 \\
\hline $\mathrm{Sb}$ & $<5$ & $\mathrm{~N} / \mathrm{A}$ & $<5$ & $<5$ & $<5$ & $<5$ & $<5$ & $<5$ & $<5$ & 6 \\
\hline $\mathrm{Sn}$ & 1 & 1 & 3 & 2 & 3 & 1 & 1 & 1 & 1 & $\mathrm{~N} / \mathrm{A}$ \\
\hline $\mathrm{Sr}$ & 274 & 248 & 150 & 10 & 215 & 271 & 11 & 2 & 92 & 139 \\
\hline $\mathrm{Ta}$ & 2 & 2 & 2 & 3 & 2 & 1 & 0.8 & 0.4 & 2 & $\mathrm{~N} / \mathrm{A}$ \\
\hline Th & 19 & 18 & 1 & 6 & 8 & 2 & 1 & $<0.05$ & 12 & $<0.05$ \\
\hline $\mathrm{Tl}$ & 1.2 & 1.1 & 1.3 & 1.6 & 0.6 & 1.5 & $<0.5$ & 1.1 & 1 & $<0.5$ \\
\hline $\mathrm{U}$ & 2 & 2 & 1 & 2 & 3 & 0.5 & 0.5 & 0.1 & 2 & $<0.5$ \\
\hline $\mathrm{V}$ & 15 & 9 & 14 & $<5$ & 5 & 355 & $<5$ & 6 & 14 & 26 \\
\hline W & 1 & 1 & 1 & 1 & 3 & 6 & 7 & $<1$ & 5 & $<1$ \\
\hline $\mathrm{Zn}$ & 47 & 37 & 9 & 20 & 10 & 148 & 17 & 6 & 37 & 61 \\
\hline $\mathrm{Zr}$ & 235 & 207 & 13 & 34 & 61 & 199 & 11 & 2 & 244 & $\mathrm{~N} / \mathrm{A}$ \\
\hline
\end{tabular}


(a)

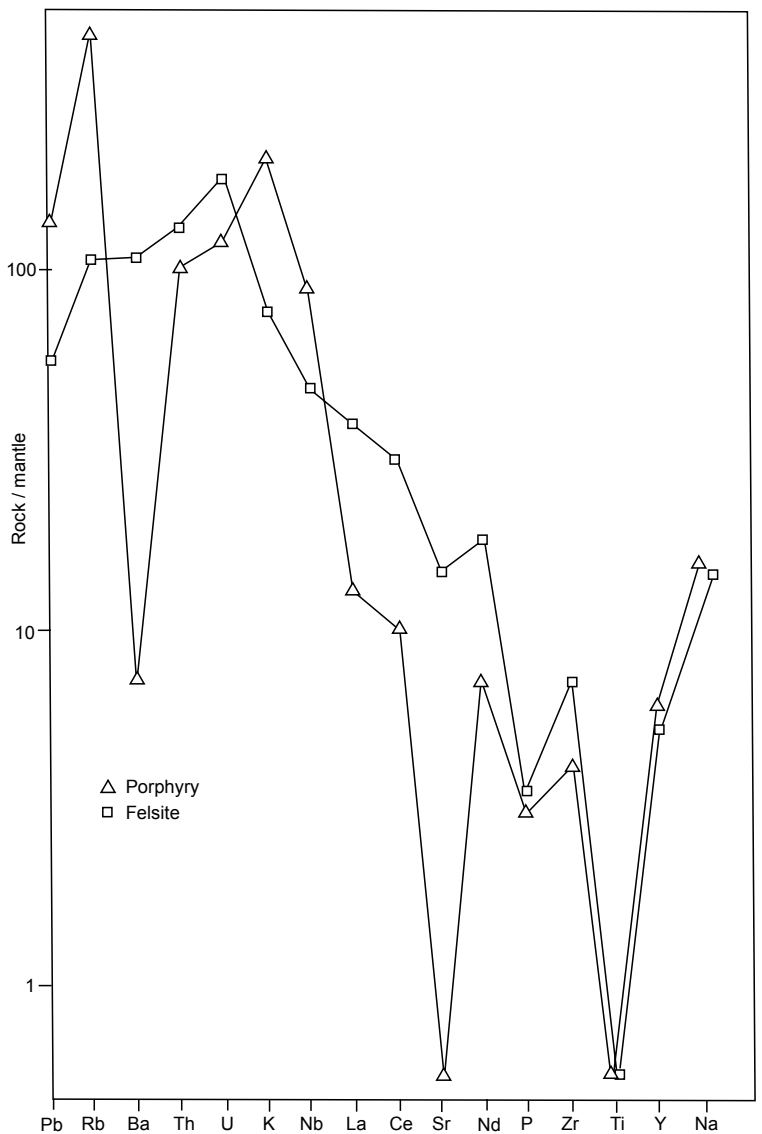

(c)

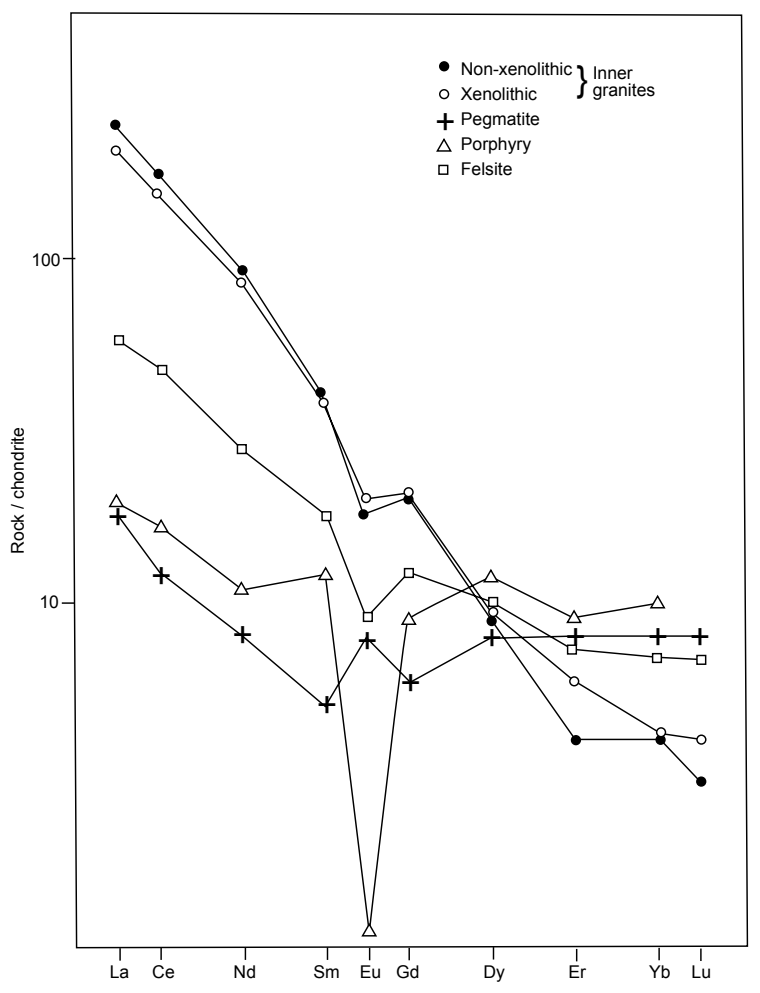

(b)

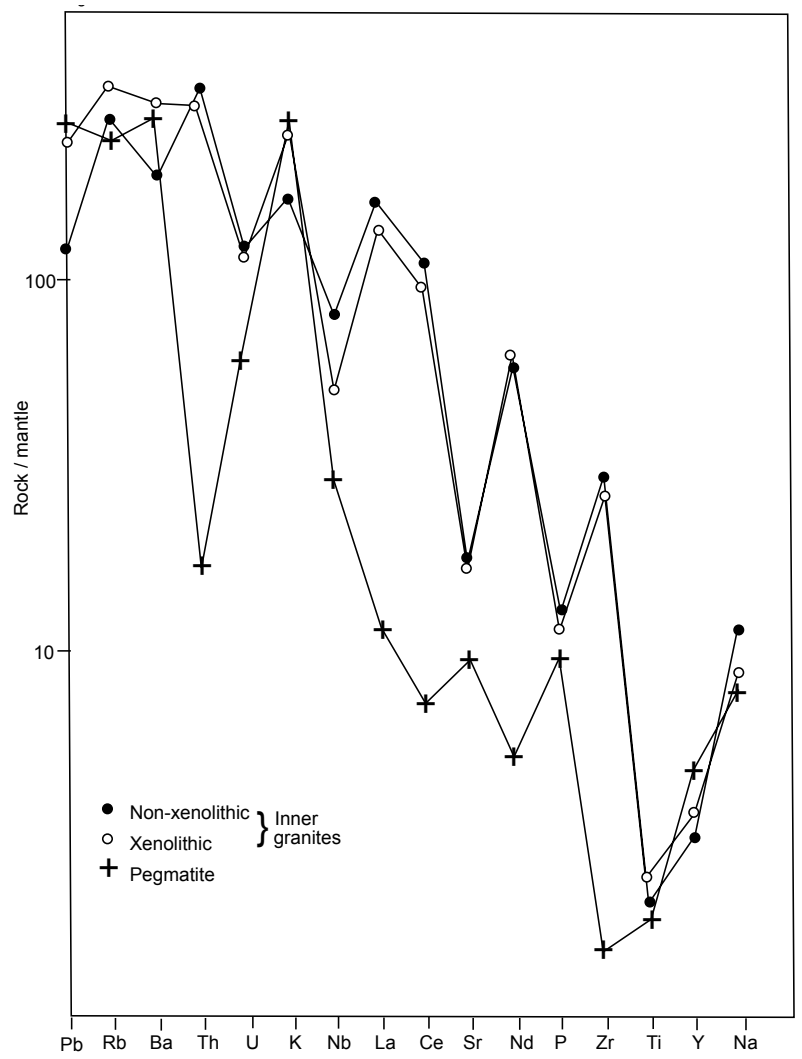

(d)

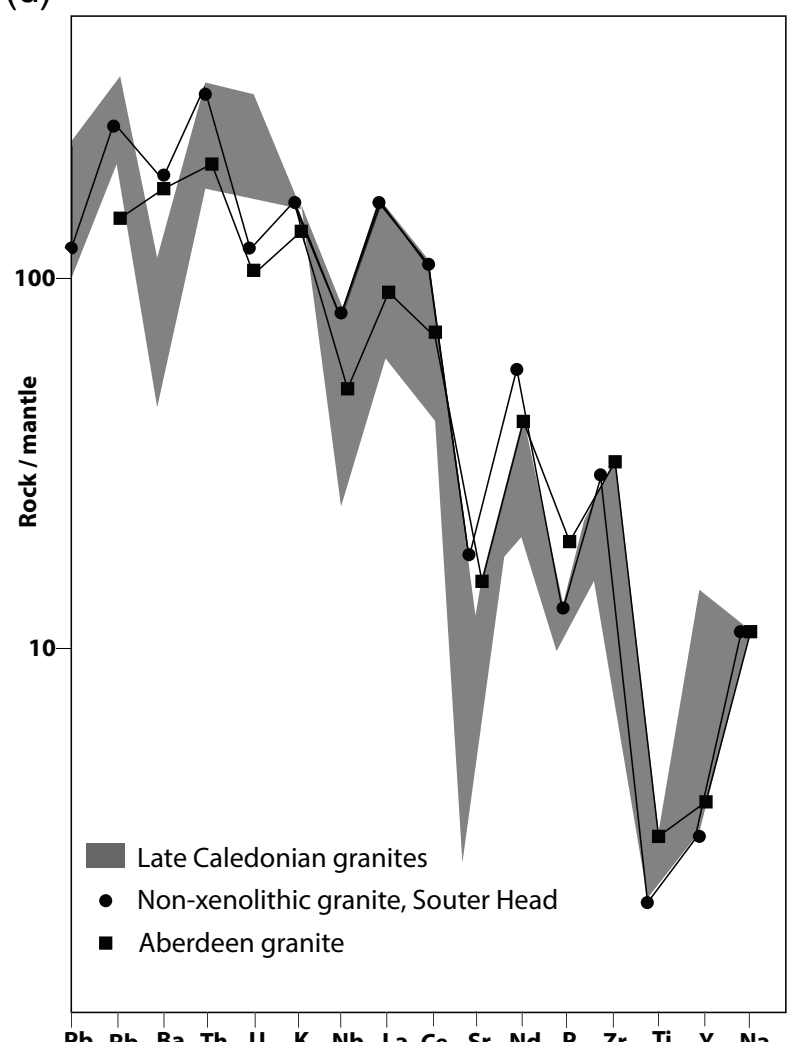

Figure 5 Multi-element variation diagrams for the SHSC. $(a, b)$ Normalised against primitive mantle values from Lyubetskaya \& Korenaga (2007). Elements are arranged in order of increasing incompatibility (right to left) with respect to the mantle source (Sun \& McDonough 1989). The figures represent the integrated effects of all the processes that have contributed to the formation of the granites and, generally, these cannot be individually identified. (c) Normalised against chondrite values from Korotev et al. 2009. (d) Comparison of the non-xenolithic granite from Souter Head with the Aberdeen granite (Ordovician) and Late Caledonian granites (Tarney \& Jones, 1994, fig. 8). 
Mo at 3790 and $41 \mathrm{ppm}$, respectively. The absence of heavy metals such as tin (Sn) and tungsten (W) is discussed later.

Non-xenolithic granite from a linear alteration zone has much less calcium oxide $(\mathrm{CaO}), \mathrm{Na}_{2} \mathrm{O}$ and $\mathrm{Sr}$, and higher loss on ignition (LOI) than outside the zone (Table 1). This reflects plagioclase replacement by kaolinite. Altered granite contains weakly anomalous As (31 ppm), Mo (14 ppm), W (5 ppm) and Au (10 ppb).

The remaining igneous rocks show no significant enrichments in the economically important elements noted in the veins or other potentially valuable elements such as copper $(\mathrm{Cu})$ and zinc $(\mathrm{Zn})$. There are scattered slightly higher levels compared to bulk crust of As, $\mathrm{Au}, \mathrm{Bi}, \mathrm{Mo}$ and lead $(\mathrm{Pb})$ (Table 1). There is no strong evidence of a link between metal enrichment and fractionation; for example, the most fractionated rock, the quartz porphyry, is not enriched. More likely, the widespread hydrothermal alteration is probably responsible for these weak enrichments.

\section{Discussion}

\subsection{The SHSC and the late-tectonic S-type granites of NE Scotland}

The petrography, geochemistry, field relations and age of the SHSC clearly link it to the late-tectonic S-type granites of NE Scotland (Strachan et al. 2002). Specifically, these include the presence of two micas, peraluminous affinity, high silica content, similar trace element compositions, sharp contacts between outer granites and country rocks and numerous partially digested xenoliths (Tarney \& Jones 1994; Strachan et al. 2002; Appleby et al. 2010). A unique feature of this complex is the presence of subvolcanic intrusion breccias.

Various features of the SHSC in common with other granites of this group are consistent with the dominant involvement of continental crust in its formation. These include common partially digested metasediment xenoliths, high silica content, strongly peraluminous nature and rock/bulk crust ratios for many trace elements close to one. Appleby et al. (2010) have argued for an additional infracrustal component in the Nigg Bay granite $5 \mathrm{~km} \mathrm{~N}$ of the SHSC. The dominant crustal component in the magmas and emplacement during rapid exhumation (Mark et al. 2019) suggest that decompressional melting of the upper crust was a key factor in melt production (Oliver 2001).

\subsection{Unique preservation of the upper levels of the igneous complex}

Souter Head is the only Ordovician granitic complex known in the Grampian terrane, where the upper levels are preserved. It is also close to Late Caledonian granites (Mount Battock and Hill of Fare, Fig. 6), which are more deeply eroded. This paradox could be explained by pre-Devonian movements on the nearby Dee fault and perhaps partly by downfaulting following collapse of the magma chamber roof (see Section 5.3). The truncation of the Aberdeen granite against this fault (Fig. 6) is consistent with significant downthrow to the S. There was later reverse movement on this fault to preserve Devonian sediments around Aberdeen.

\subsection{Magmatic-hydrothermal evolution of the complex}

The excellent exposures of contact relationships in the coastal transect permit a cross-section of the complex (Fig. 7) and the magmatic-hydrothermal evolution of the complex to be reconstructed in some detail (Fig. 8a-f). Rapid exhumation (Mark et al. 2019) may have been partly responsible for the repeated fracturing and explosive activity described in the following sections. The evolutionary sequence presented here requires the inner granites to postdate the intrusive breccia (see Section 2.3.1) and interprets the Burnbanks and Bunstane granites and granite clasts in the breccias as remnants of an early carapace.

5.3.1. Stage 1. Emplacement of a peraluminous granite magma in the upper crust and carapace formation (Fig. 8a). During cooling, volatiles collected in the magma chamber roof, which eventually exploded, forming large breccia bodies (Fig. 8b). As fluid pressures subsided, the roof and breccias collapsed into the chamber. Blocks of breccia were invaded by magma to give a partial igneous matrix (Fig. 8c). This magma cooled to form the inner granites. The present distribution of breccia units reflects this collapse, with later adjustments straightening the contacts (Figs 1,7). The evidence for the early age of this event is the sealing and crosscutting of contacts by porphyry and quartz veins.

5.3.2. Stage 2. Following cooling and reforming of the chamber roof it was refractured along N-S and NNE-SSW

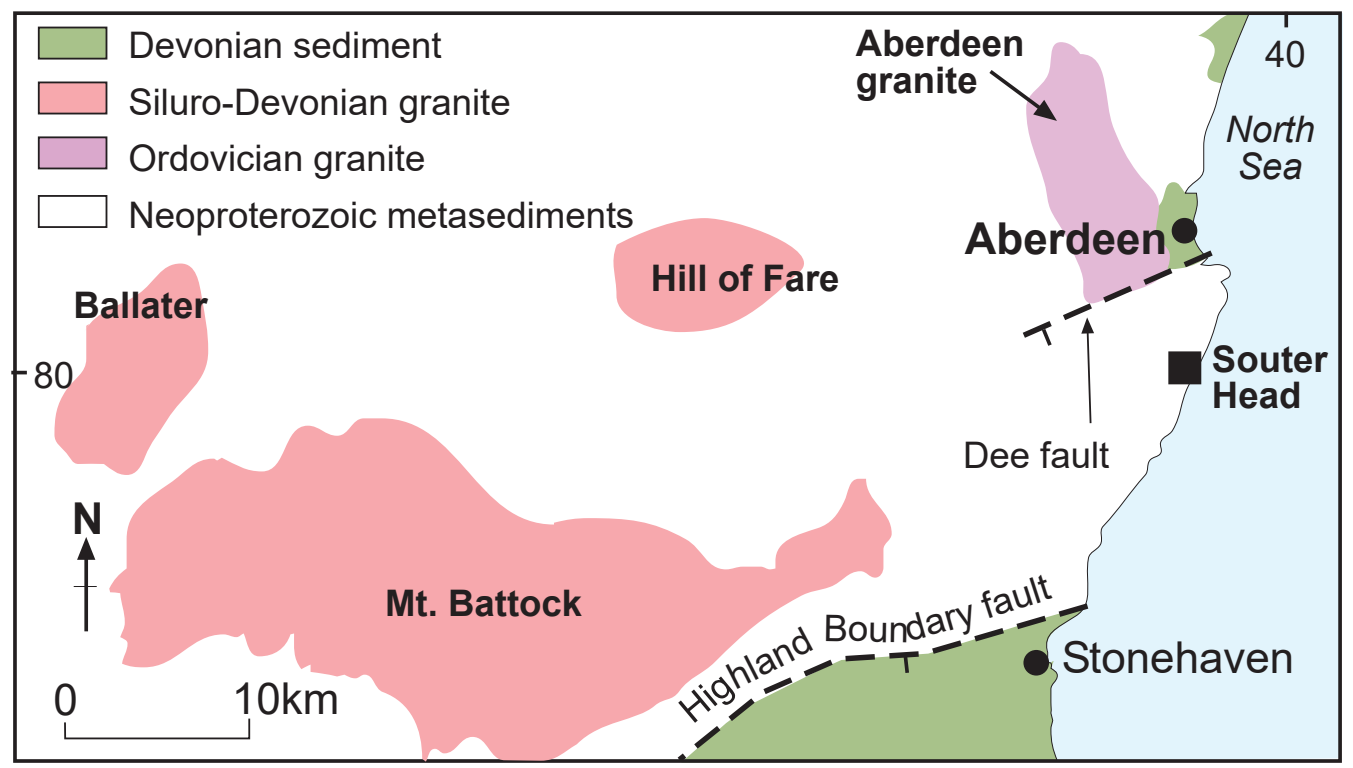

Figure 6 Relationship of the SHSC to the Aberdeen granite, nearest Late Caledonian granites and the Dee and Highland Boundary Faults. 


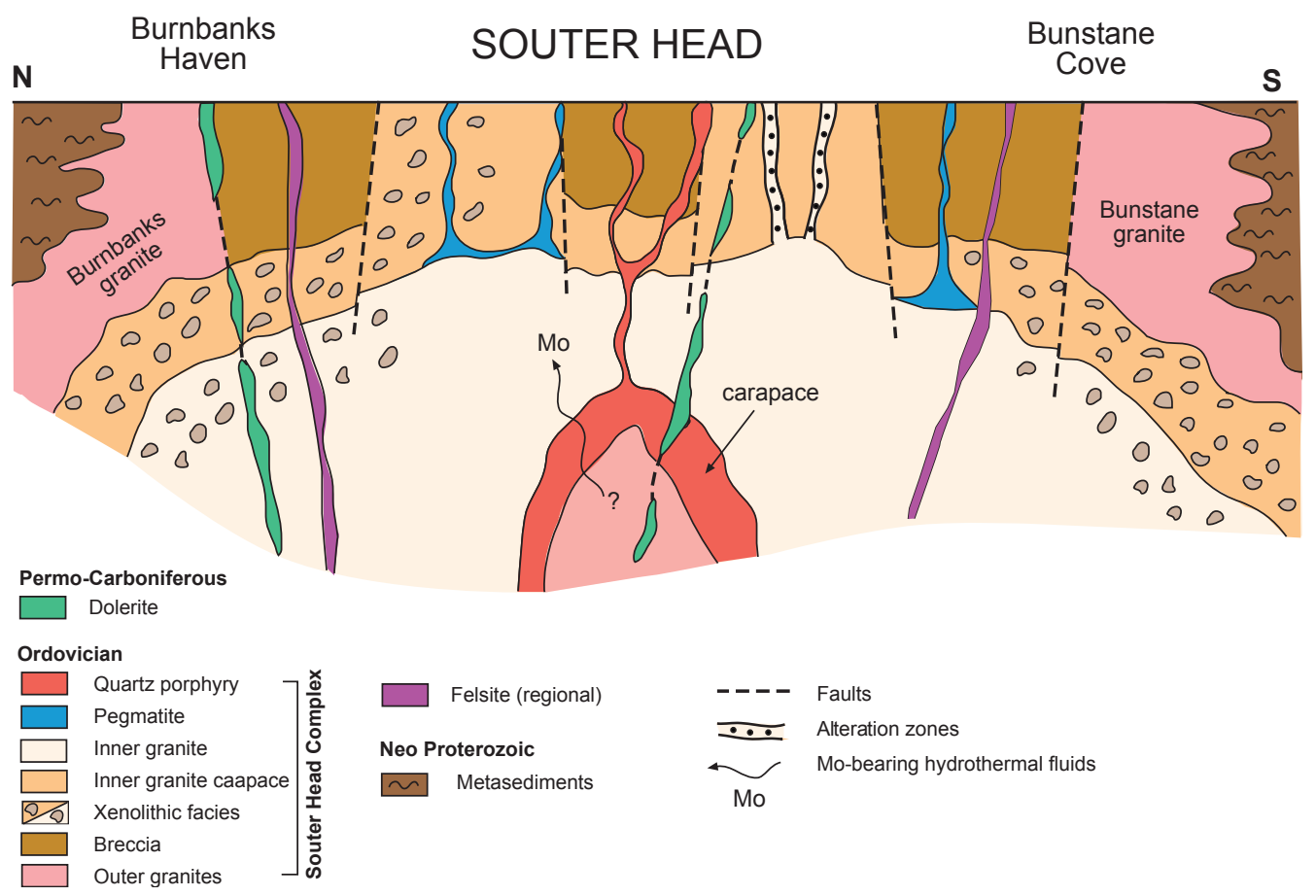

Figure 7 Cross-section of the SHSC. Quartz veins omitted for clarity.

directions. Fractures were best developed in granite due to its greater competency. Residual volatile-rich portions of this magma were injected into fractures to form pegmatites and linear alteration zones (Fig. 8d). Volatile-rich magma also invaded breccia to form small irregular bodies of pegmatite. Whereas pegmatites represent passive injection of fluids, the linear alteration zones record the injection of high-pressure fluids from a breached cupola. These caused hydraulic fracturing and intense alteration along the fractures. Later fluids produced quartz veins and minor Mo mineralisation. This episode of volatile release resulted in further collapse of the chamber and adjustments along granite-breccia contacts causing truncation of pegmatites and linear alteration zones (Fig. 2g, k).

5.3.3. Stage 3. New chamber established in which strong crystal fractionation occurred to generate quartz porphyry magma. The chamber was disrupted by NW-SE and E-W fractures into which magma was intruded (Fig. 8e). The porphyry intruded a major breccia-granite contact and marked the end of movement along this contact (Fig. 2h, i).

5.3.4. Stage 4. The complex cooled rapidly, possibly caused by rapid exhumation (Mark et al. 2019), before further complex-wide fracturing and multiple episodes of hydrothermal activity, possibly linked to a deeper chamber (Fig. 8f). N-S quartz veins cut some of the main breccia-granite contacts, showing that movement had ceased along these. This stage marks the end of magmatic and hydrothermal activity, which lasted about $1 \mathrm{Ma}$ (Mark et al. 2019)

\subsection{Classification of mineralisation}

The styles and location of Mo mineralisation, composition of intrusives and evidence of progressive fractionation indicate a granite-related vein-type deposit (Lowry 1991; Cerny et al. 2005). Specifically, the styles are Mo occurring in quartz veins within granite-hosted alteration zones and also in brecciahosted veins near to granite.

According to Cerny et al. (2005), granite-related systems are typically emplaced at depths of $1.5-5 \mathrm{~km}$. Intrusion breccia, various brittle features and porphyritic textures in the SHSC are consistent with these depths. Dominant kaolinite alteration in the linear alteration zones as opposed to muscovite is atypical of these deposits. However, muscovite may have been replaced by kaolinite during a younger thermal event at $c a .405 \mathrm{Ma}$ linked to nearby Late Caledonian granites (Fig. 6) (Mark et al. 2019).

Quartz porphyry is the youngest known intrusion and several parameters - i.e., $\mathrm{Rb} / \mathrm{Sr}$ and ferric oxide $\left(\mathrm{Fe}_{2} \mathrm{O}_{3}\right) /$ ferrous oxide $(\mathrm{FeO})$ ratios of 21.3 and 0.8 respectively, the presence of magnetite and low levels of Sn and $\mathrm{W}$ - indicate that the SHSC is in the most oxidised and most evolved category of this class, where, typically, Mo is exclusively concentrated (Cerny et al. 2005, fig. 7).

In addition to $\mathrm{Mo}$, small quantities of $\mathrm{Au}, \mathrm{As}$ and $\mathrm{Bi}$ are found in quartz-pyrite veins at Souter Head. Significant concentrations of these metals occur in other granite-related systems, where magmato-hydrothermal processes may have been similar. For example, at Timbarra in Australia, Au and Mo are concentrated by fractional crystallisation of a magnetitebearing, peraluminous granite magma (Mustard 2001; Mustard et al. 2006).

The SHSC is a rare example of Ordovician hydrothermal mineralisation in the Grampian terrane, and the only known example of granite-related mineralisation of this age in this terrane. Quartz-vein-hosted $\mathrm{Au}-\mathrm{Mo}$ mineralisation of similar age occurs at Curraghinalt in northern Ireland, but there is no known coeval intrusive activity and it is classified as an orogenic Au deposit (Rice et al. 2016).

\subsection{Exploration potential of the SHSC and surrounding area}

Certain features suggest that the SHSC is prospective for additional Mo and possibly Au mineralisation. These are the large size, lack of exposure, volatile-rich nature and abundant quartz veining. Specifically, the complex could host porphyryMo-style stockwork mineralisation (Seedorf et al. 2005) at depth and $\mathrm{Au}$ mineralisation in the roof of underlying pluton(s) or disseminated in breccias or in quartz vein complexes.

In a regional context, the period $c a .470 \mathrm{Ma}$ in the Grampian terrane favoured the generation of large mineralised 
(a)

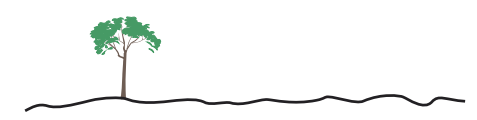

SEMI-PELITES

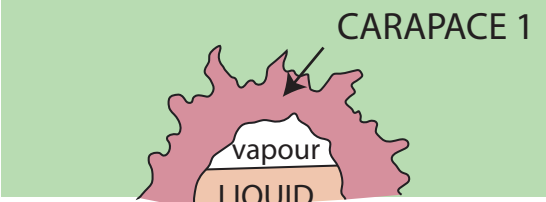

(b)
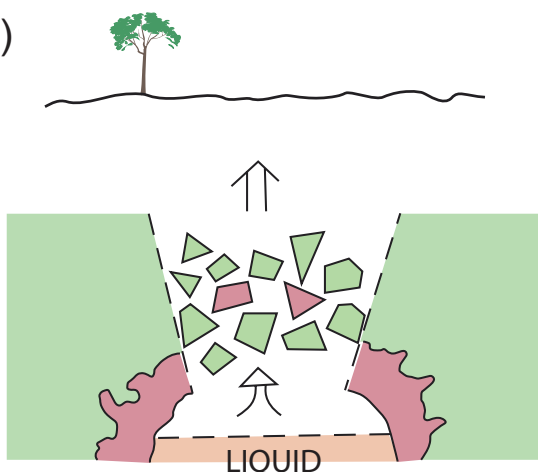

(c) SUPERSTRUCTURE OMITTED

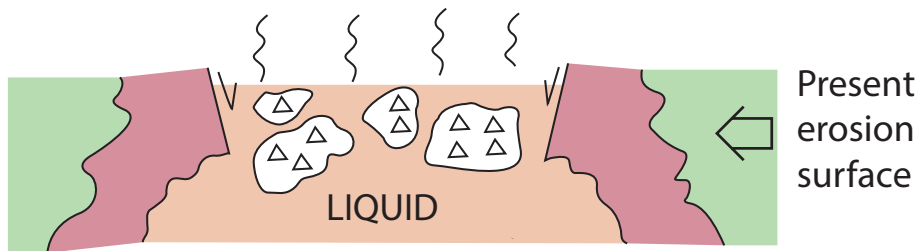

(d)

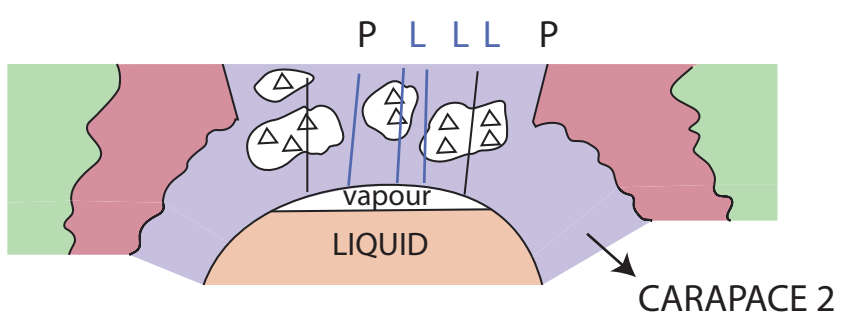

(e)

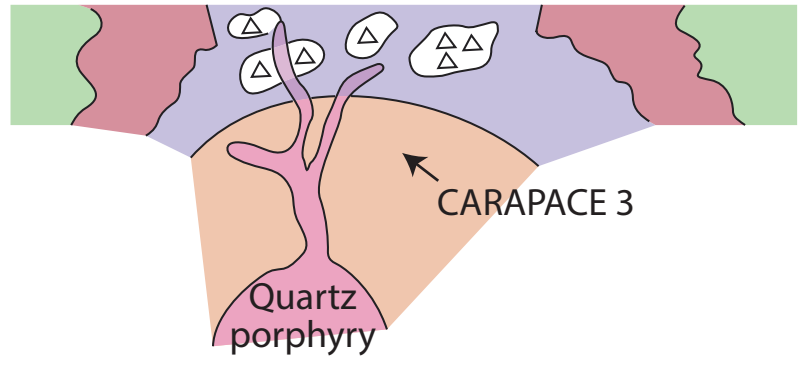

(f)

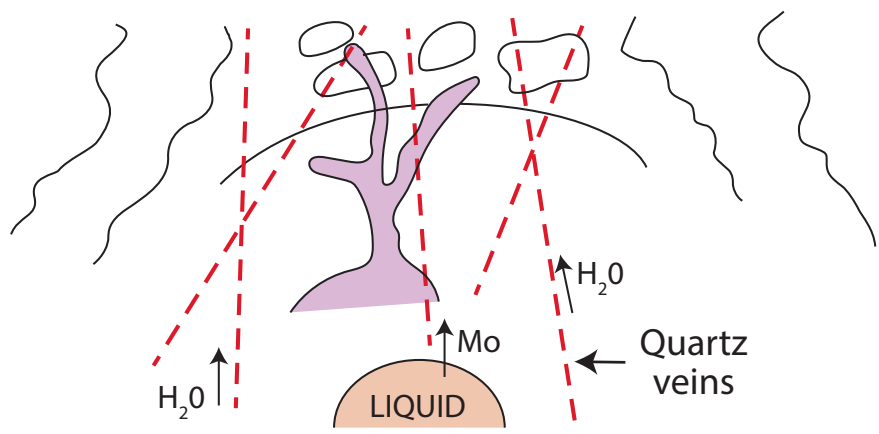

Figure 8 Evolution of the SHSC. (a) Emplacement of a peraluminous granite magma in the upper crust. Volatiles collect in the roof. (b) Magma chamber explodes with formation of breccia bodies. (c) Chamber roof and breccias collapse into chamber. Magma invades blocks of breccia. Superstructure omitted for clarity. (d) System cools and new chamber forms at depth. Further movements fracture the roof. Fractures filled by volatile-rich fluid to form pegmatites and linear alteration zones and minor molybdenite mineralisation. (e) Further cooling and new chamber forms. Fractionation generates the quartz porphyry magma. (f) Cooling continues, $\mathrm{N}-\mathrm{S}$ fracturing, hydrothermal activity and formation of group 2 quartz veins and $\mathrm{Mo}-\mathrm{Bi}-\mathrm{As}-\mathrm{Au}$ mineralisation. Hydrothermal activity possibly linked to deeper chamber. 
hydrothermal systems in the upper crust. Key factors were uplift and extension, increasing crustal permeability and magmas accessing the crust along major structures to provide sources of heat and metals (Ashcroft et al. 1984; Viete et al. 2010; Mark et al. 2019). Despite deep levels of erosion over much of the terrane, making the preservation of such systems unlikely, the SHSC shows that in favourable circumstances they have survived. Exploration for similar systems to the SHSC should focus, therefore, on areas containing S-type granites, quartz veins and breccias associated with inferred downfaulting such as the sector between the Dee fault and the Highland Boundary fault (Fig. 6).

\section{Conclusions}

The SHSC is a large late-orogenic intrusive complex showing multiple stages of faulting, magma and breccia intrusion and hydrothermal activity. It was emplaced during a period of rapid exhumation, which may have facilitated repeated faulting, explosive release of volatiles and rapid cooling of the system. The unique preservation of an Ordovician subvolcanic complex in the Grampian terrane could be explained by putative pre-Devonian movements on the nearby Dee fault.

Complex formation was initiated by shallow emplacement of a peraluminous granite magma, explosive release of volatiles and formation of breccias. As the fluid flux subsided the breccia column collapsed into the magma chamber. Reforming of the chamber roof and subsequent rupture led to further volatile release along linear fracture zones and intense wallrock alteration. Injection of fractionated quartz porphyry dykes is the final magmatic phase observed. Further fracturing and cooling was accompanied by extensive and episodic hydrothermal activity and $\mathrm{Mo}$ and $\mathrm{Au}-\mathrm{Bi}-\mathrm{As}$ mineralisation, marking the end of magmatic and hydrothermal activity. The Souter Head magmas were derived largely by melting of upper-crustal Dalradian metasediments. Crystal fractionation under oxidising conditions was responsible for the Mo and $\mathrm{Au}-\mathrm{As}-\mathrm{Bi}$ mineralisation. The mineralisation is a Mo-rich end member of the granite-related style of mineralisation.

The large size, multiple phases of hydrothermal activity and poor exposure indicate that the complex is prospective for further Mo and possibly $\mathrm{Au}$ mineralisation. Upper-crustal mineralisation of Ordovician age is preserved in the Grampian terrane in suitable tectonic settings and should be included in an exploration programme.

\section{Acknowledgements}

We would like to thank Jenny Johnston and Jamie Bowie (School of Geosciences, University of Aberdeen) for drafting the figures.

\section{References}

Appleby, S. K., Gillespie, M. R., Graham, C. M., Hinton, R. W. Oliver, G. J. H. \& Kelly, N. M. 2010. Do S-type granites commonly sample infracrustal sources? New results from an integrated $\mathrm{O}, \mathrm{U}-\mathrm{Pb}$ and $\mathrm{Hf}$ isotope study of zircon. Contributions to Mineralogy and Petrology 160, 115-32.

Ashcroft, W. A., Kneller, B. C., Leslie, A. G. \& Munro, M. 1984 Major shear zones and autochthonous Dalradian in the northeast Scottish Caledonides. Nature 310, 760-62.

Cerny, P., Blevin, P. L., Cuney, M. \& London, D. 2005. Graniterelated ore deposits. In Hedenquist, J. W., Thompson, J. F. H., Goldfarb, R. J. \& Richards, J. P. (eds) Economic geology $100^{\text {th }}$ anniversary volume, 337-70. Littleton, Colorado: Society of Economic Geologists.
Halliday, A. N., Stephens, W. E. \& Harmon, R. S. 1981. Isotopic and chemical constraints on the development of peraluminous Caledonian and Acadian granites. Canadian Mineralogist 19, 205-16.

Halliday, A. N. \& Stephens, W. E. 1984. Crustal controls on the genesis of the $400 \mathrm{Ma}$ old Caledonian granites. Physics of the Earth and Planetary Interiors 35, 89-104.

Harker, S. D. 2002. Cretaceous. In Trewin, N. H. (ed.) The geology of Scotland, 4th edn, 351-60. London: The Geological Society.

Kneller, B. C. \& Gillen, C. 1987. Aberdeen city and environs. In Trewin, N. H., Kneller, B. C. \& Gillen, C. (eds) Excursion guide to the geology of the Aberdeen area, 55-64. Geological Society of Aberdeen. Edinburgh: Scottish Academic Press.

Korotev, R. L., Ziegler, R. A., Jolliff, B. L., Irving, A. J. \& Bunch, T. E. 2009. Compositional and lithological diversity among brecciated lunar meteorites of intermediate iron concentration. Meteoritics \& Planetary Science 44, 1287-322.

Lowry, D. 1991. The genesis of Late Caledonian granitoid-related mineralization in Northern Britain. PhD Thesis, University of St Andrews, Scotland.

Lyubetskaya, T. \& Korenaga, J. 2007. Chemical composition of earth's primitive mantle and its variance. Journal Geophysical Research 112, B03211.

Mark, D. F., Rice, C. M., Fallick, A. E., Trewin, N. H., Lee, M. R., Boyce, A. J. \& Lee, J. K. W. 2011. ${ }^{40} \mathrm{Ar} /{ }^{39} \mathrm{Ar}$ dating of hydrothermal activity, biota and gold mineralization in the Rhynie hot-spring system, Aberdeenshire, Scotland. Geochimica et Cosmochimica Acta 75, 555-69.

Mark, D. F., Rice, C. M. \& Condon, D. J. 2019. Multi-chronometer dating of an Ordovician sub-volcanic complex, Aberdeenshire, Scotland: Rapid exhumation terminates the Grampian event of the Caledonian Orogeny. Earth and Environmental Science Transactions of the Royal Society of Edinburgh. In review.

Munro, M. 1986. Geology of the area around Aberdeen (Memoir Sheet 77). London: B.G.S., H.M.S.O. 128 pp.

Mustard, R. 2001. Granite-hosted gold mineralization at Timbarra, northern New South Wales, Australia. Mineralium Deposita 36, $542-62$.

Mustard, R., Ulrich, T., Kamenetsky, V. S. \& Mernagh, T. 2006. Gold and metal enrichment in natural granitic melts during fractional crystallization. Geological Society of America 34, 85-88.

Oliver, G. J. H. 2001. Reconstruction of the Grampian episode in Scotland: its place in the Caledonian Orogeny. Tectonophysics 332, 23-49.

Oliver, G. J. H., Wilde, S. A. \& Wan, Y. 2008. Geochronology and geodynamics of Scottish granitoids from the late Neoproterozoic break-up of Rodinia to Palaeozoic collision. Journal Geological Society London 165, 661-74.

Paterson, S. R., Vernon, R. H. \& Tobisch, O. T. 1989. A review of criteria for the identification of magmatic and tectonic foliations in granitoids. Journal Structural Geology 11, 349-63.

Porteous, W. G. 1973. A breccia pipe in the Dalradian series, East Kincardineshire. Scottish Journal Geology 9, 233-37.

Read, W. A., Browne, M. A. E., Stephenson, D. \& Upton, B. G. J. 2002. Carboniferous. In Trewin, N. H. (ed.) The geology of Scotland, 251-99. London: The Geological Society.

Rice, C. M., Mark, D. F., Selby, D. \& Hill, N. J. 2012. Dating vein-hosted Au deposits in the Caledonides of N. Britain. Mineral Deposits Studies Group meeting abstracts. Transactions of the Institute of Mining and Metallurgy (Section B: Applied Earth Science) 121, 199-200.

Rice, C. M., Mark, D. F., Selby, D., Neilson, J. E. \& DavidheiserKroll, B. 2016. Age and geologic setting of quartz vein-hosted gold mineralization at Curraghinalt, Northern Ireland: Implications for genesis and classification. Economic Geology 111, 12750 .

Rudnick, R. L. \& Gao, S. 2003. Volume 3: The crust, 3.01 - The composition of the Continental crust. In Holland, H. D. \& Turekian, K. K. (eds) Treatise on geochemistry, 1-64. Oxford: Elsevier-Pergamon.

Seedorf, E., Dilles, J. H., Proffett, J. M. Jr., Einaudi, M. T., Zurcher, L., Stavast, W. J. A., Johnson, D. A. \& Barton, M. D. 2005. Porphyry deposits: characteristics and origin of hypogene features. In Hedenquist, J. W., Thompson, J. F. H., Goldfarb, R. J. \& Richards, J. P. (eds) Economic geology $100^{\text {th }}$ anniversary volume, 251-98. Littleton, Colorado: Society of Economic Geologists.

Sillitoe, R. H. 1985. Ore-related breccias in volcanoplutonic arcs. Economic Geology 80, 1467-514.

Stephenson, D. \& Gould, D. 1995. The Grampian Highlands. British Geological Survey, 261 pp. London: HMSO. 
Strachan, R. A., Smith, M., Harris, A. L. \& Fettes, D. J. 2002. The Northern Highland and Grampian terranes. In Trewin, N. H. (ed.) The geology of Scotland, 81-147. London: The Geological Society.

Sun, S. S. \& McDonough, W. F. 1989. Chemical and isotopic systematics of oceanic basalts: Implications for mantle composition and processes. Geological Society London Special Publications 42, 313-45.

Tarney, J. \& Jones, C. E. 1994. Trace element geochemistry of orogenic rocks and crustal growth models. Journal of the Geological Society, London 151, 855-68.
Viete, D. R., Richards, S. W., Lister, G. S., Oliver, G. J. H. \& Banks, G. J. 2010. Lithospheric-scale extension during Grampian orogenesis in Scotland. In Law, R. D., Butler, R. W. H., Holdsworth, R. D., Krabbendam, M. \& Strachan, R. A. (eds) Continental tectonics and mountain building: The legacy of Peach and Horne, 121-60. Geological Society Special Publications 335. London: The Geological Society.

MS received 13 April 2018. Accepted for publication 19 July 2019. First published online 11 May 2020 